\title{
Intraplate uplift: new constraints on the Hoggar dome from the Illizi basin (Algeria)
}

DOI:

10.1111/bre.12182

\section{Document Version}

Accepted author manuscript

Link to publication record in Manchester Research Explorer

\section{Citation for published version (APA):}

English, K., Redfern, J., Bertotti, G., English, J. M., \& Yahia Cherif, R. (2016). Intraplate uplift: new constraints on the Hoggar dome from the Illizi basin (Algeria). Basin Research, 1. https://doi.org/10.1111/bre.12182

\section{Published in:}

Basin Research

\section{Citing this paper}

Please note that where the full-text provided on Manchester Research Explorer is the Author Accepted Manuscript or Proof version this may differ from the final Published version. If citing, it is advised that you check and use the publisher's definitive version.

\section{General rights}

Copyright and moral rights for the publications made accessible in the Research Explorer are retained by the authors and/or other copyright owners and it is a condition of accessing publications that users recognise and abide by the legal requirements associated with these rights.

\section{Takedown policy}

If you believe that this document breaches copyright please refer to the University of Manchester's Takedown Procedures [http://man.ac.uk/04Y6Bo] or contact uml.scholarlycommunications@manchester.ac.uk providing relevant details, so we can investigate your claim.

\section{OPEN ACCESS}




\title{
Cenozoic uplift of the Hoggar Region, North Africa: constraints from its northern flank (Illizi basin, Algeria)
}

\author{
Kara L. English \\ Petroceltic International Plc, $5^{\text {th }}$ Floor, 3 Grand Canal Plaza, Grand Canal Street Upper, Dublin \\ 4, Ireland. Phone: +353 1421 8300; E-mail: kara.english@yahoo.ca \\ Jonathan Redfern
}

School of Earth, Atmospheric and Environmental Sciences, University of Manchester, Williamson Building, Oxford Road, Manchester, M13 9PL, United Kingdom; E-mail: jonathan.redfern@manchester.ac.uk

\section{Giovanni Bertotti}

Geoscience and Engineering, Delft University of Technology, Stevinweg 1, 2628CN, Delft, The Netherlands; E-mail: G.Bertotti@tudelft.nl

\section{Joseph M. English}

Petroceltic International Plc, $5^{\text {th }}$ Floor, 3 Grand Canal Plaza, Grand Canal Street Upper, Dublin 4, Ireland. Phone: +353 1421 8300; E-mail: joseph.english@petroceltic.com

\section{Rachida Yahia Cherif}

Direction Coordination Groupe Associations - Sonatrach, Djenane El-Malik, Hydra, Alger, Algérie (Algeria); E-mail: Rachida.Yahiacherif@Sonatrach.dz

Submitted to Basin Research, July $27^{\text {th }}, 2015$

Revision submitted to Basin Research, November 13, 2015

Second Revision submitted to Basin Research, January 3, 2016

Main text word count $=5960$

Abstract word count $=182$

Number of references $=85$

Number of tables $=3$

Number of figures $=7$

Data Repository $=$ Yes

Corresponding author $=$ Kara English 


\section{ABSTRACT}

30 Zones of anomalously high topography within continental interiors, distant from active plate boundaries, are interpreted as being either dynamically supported by viscous flow in the underlying mantle or influenced by plate tectonics. Constraining the models of their genesis requires accurate data on the timing and dimensions of such features. New apatite fission-track and thermal maturity data from the Illizi Basin in Algeria quantifies the magnitude and timing of kilometre-scale uplift and exhumation of the northern flank of the Hoggar swell in North Africa. The findings of this study, integrated with previously published thermochronological data, confirm that long wavelength regional uplift occurred during the Cenozoic extending over a distance in excess of $1,500 \mathrm{~km}$ from north to south. The uplift evidenced in the Hoggar Massif significantly impacted the flanking Illizi and Tim Mersoï basins. The combination of thermal history modelling and regional stratigraphic observations indicates that the onset of exhumation of the Illizi Basin likely occurred during the Eocene, broadly coincident with magmatism on the Hoggar Massif to the south and the onset of tectonic shortening in the Atlasic belt to the north. 
44

45

46

\section{INTRODUCTION}

Zones of anomalously high topography within continental interiors, far away from active plate boundaries, are often interpreted as being dynamically supported by viscous flow in the underlying mantle (e.g. Braun, 2010; Al-Hajri et al., 2009; Moucha \& Forte, 2011; Jones et al., 2012). The average diameter of modern topographic swells across Africa and Antarctica is 1850 $\pm 450 \mathrm{~km}$, and associated gravity anomalies suggest that the full height of dynamically supported topography ranges from 800 to $1800 \mathrm{~m}$ (Jones et al., 2012). Long-wavelength basins and swells characterize the present-day topography of Africa (Holmes, 1944; Burke, 1996). Northern Africa is characterised by a number of prominent topographic swells, typically associated with relatively young (c. 35 Ma-Recent) volcanism (e.g. Hoggar, Tibesti, Darfur; Fig. 1), consistent with the involvement of sublithospheric processes (Sahagian, 1988; Wilson \& Guiraud, 1992; Burke, 1996; Liégeois et al., 2005; Azzouni-Sekkal et al., 2007; Beccaluva et al., 2007).

There is general consensus that mantle convection plays an important role in the formation of many modern topographic swells, but detailed surface studies are required to establish the timing and evolution of these uplifts in the geological record to provide constraints for understanding their genesis. The Hoggar Massif in central North Africa (Fig. 1) is characterized by exposed crystalline basement, and flanked by sedimentary basins. New apatite fission-track and thermal maturity data from a well in the Illizi Basin (Well A; Fig. 1), along with basin modelling and regional stratigraphic correlations, constrain both the timing and magnitude of exhumation of the northern flank of the Hoggar Massif. These new data are integrated with previously published thermochronological data from the Hoggar Massif and surrounding basins. A regional cross-section is constructed from the Illizi and Berkine basins in the north, over the Hoggar Massif, and southward across the Tim Mersoï and Iullemmeden basins (Fig. 1). This illustrates that the Cenozoic kilometric-scale rock uplift occurred over a distance in excess of $1,500 \mathrm{~km}$ from north to south.

\section{GEOLOGICAL SETTING}

The Hoggar Massif in Algeria is associated with exposed Pan-African basement extending over an area greater than $400,000 \mathrm{~km}^{2}$ (Fig. 1). The preserved Paleozoic sections north and south 
of the Hoggar Massif have broadly similar stratigraphy, with up to $2.5 \mathrm{~km}$ of sedimentary section preserved in the Illizi Basin (Galeazzi et al., 2010) to the north and in the Iullemmeden and Tim Mersoï basins (Zanguina et al., 1998) to the south. A predominance of northerly paleocurrent directions reported within Cambro-Ordovician and Devonian sandstones on the northern and southern sides of the Hoggar Massif (Beuf et al., 1971) suggests that the Hoggar Massif was not a structural high during the earlier part of the Paleozoic, and that sequences were originally deposited continuously across the Hoggar region. Following the collision of Gondwana with Laurasia, the Paleozoic sequence was variably uplifted and eroded across parts of northwest Africa during the Late Carboniferous-Early Permian Hercynian (Variscan) Orogeny (Aliev et al., 1971; Burollet et al., 1978; Boote et al., 1998; Acheche et al., 2001).

Rifting along the northern margin of the African plate during the Early Triassic records the initial breakup of Gondwana and the opening of the Tethyan seaway (e.g., Guiraud, 1998). Triassic continental clastic systems sourced from uplifted Hercynian highs, flowed northnortheast through the Berkine Basin towards the peri-Tethys (Turner et al., 2001). In response to relative sea-level rise during the Middle Triassic, marine incursion occurred across Algeria, Tunisia and western Libya leading to the formation of a restricted Triassic salt basin (Turner \& Sherif, 2007) in the northern portion of the Berkine and Oued Mya basins. Continued landward encroachment during the Late Triassic and Early Jurassic resulted in the progressive southward onlap of these successions onto older Paleozoic strata in the Illizi Basin (Galeazzi et al., 2010). On the southern flank of the Hoggar Massif, the Iullemmeden Basin was also a site of continental deposition during this time (Zanguina et al., 1998).

Some interpretations consider that the Hoggar Massif remained an exposed high since the Hercynian orogeny until present-day (Fabre, 1976; Guiraud et al., 2005; Liégeois et al., 2005) while others interpret that deposition may have occurred over the Hoggar Massif during the Late Cretaceous-Early Eocene (Swezey, 2009; Rougier et al., 2013). Evidence to support the latter interpretation are remnants of Jurassic to Cretaceous sediments that are widely preserved on the flanks of the uplifted Hoggar Massif. In the Serouenout area of northeastern Hoggar (Fig. 1), up to $350 \mathrm{~m}$ of poorly dated Upper Jurassic to Lower Cretaceous continental sandstones were deposited directly on basement (Bordet, 1954; Philippe et al., 2003). The Serouenout sediments cover an area of $\sim 6,000 \mathrm{~km}^{2}$ with no indications of the basin limit (LeFranc \& Guiraud, 1990). In 
the Amguid area in the northern Hoggar (Fig. 1), Upper Cenomanian-Lower Turonian limestones unconformably overlie basement (Busson et al., 1999). These outcrops lie along trend from the basement-controlled north-south oriented Amguid-El Biod High to the north (Fig. 1). This structure was the site of major transpressional deformation during the Late Neocomian-Middle Aptian Austrian event (Galeazzi et al., 2010), and the presence of the Amguid limestones indicates at least partial inundation of this high during the Late Cretaceous. The short-lived Austrian tectonic event was characterized by strike-slip deformation along major intra-plate basement structures in North Africa, and was likely associated with the break-up of the Equatorial Atlantic and rifting in Central Africa (Guiraud et al., 2005; Galeazzi et al., 2010).

In general, the Cenozoic stratigraphy of the Sahara records a transition from early Cenozoic carbonate deposition to late Cenozoic siliciclastic deposition (Swezey, 2009). North of the Hoggar, outcrops of marine carbonates in the Tademait region (Fig. 1) record deposition during the Late Cretaceous to Early Eocene. This sequence is capped by an unconformity, which is locally overlain by either Upper Eocene-Oligocene fluvial sandstones or Miocene-Pliocene fluvial sandstones and conglomerates (Swezey, 2009). In the Iullemmeden Basin, latest Paleocene to Eocene marine deposits are capped by continental Eocene to Miocene deposits; these sequences are separated by unconformities typically assigned to the Late Paleocene and Late Eocene-Oligocene (Kogbe, 1981; Burke \& Gunnell, 2008). Clastic deposits of Late EocenePliocene age in the Saharan region are collectively referred to as the "Continental Terminal" (Kilian, 1931; Lang et al., 1990). Magmatic activity in the Hoggar area began at the EoceneOligocene boundary ( $\sim 34 \mathrm{Ma})$ and has continued until the present (Girod, 1971; Aït Hamou et al., 2000; Liégeois et al., 2005; Azzouni-Sekkal et al., 2007).

\section{PREVIOUS STUDIES OF HOGGAR UPLIFT}

Evidence of rock uplift, defined as vertical displacement of rock compared to a fixed frame of reference (England \& Molnar, 1990), is observed in the core of the Hoggar, where the Precambrian basement attains average elevations of 1,000-1,500 m a.s.l. (Lesquer et al., 1990), while locally reaching elevations of $\sim 2,400 \mathrm{~m}$ a.s.1. in the Atakor region (Fig. 1) (Girod, 1971). The Upper Jurassic to Lower Cretaceous sandstones at Serouenout mostly occur at elevations 
132

133

134

135

136

137

138

139

140

141

142

143

144

145

146

147

148

149

150

151

152

153

154

155

156

157

158

159

160

between 1,200 and 1,400 $\mathrm{m}$ a.s.1., although they can reach up to 1,700 $\mathrm{m}$ a.s.1. (Rougier, 2012). Sahagian (1988) used the distribution of Cenomanian shoreline deposits from the Trans-Sahara seaway preserved near the Hoggar to estimate that $2-3 \mathrm{~km}$ of uplift likely occurred in the area post-Cenomanian deposition. Volcanic centres, such as Mt. Tahat (2,909 m a.s.1.) in the Atakor area (Fig. 1), developed locally on top of the broader Hoggar swell during the Cenozoic.

Previous thermochronological analyses in the region have mainly focussed on outcrops from the Hoggar Massif (Carpena et al., 1988; Meyer, 1990; Cavellec, 2006; Rougier et al., 2013). Rougier et al. (2013) collected extensive apatite (U-Th)/He data and determined that the last phase of cooling and exhumation of the Hoggar Massif likely occurred during the Eocene. Apatite fission-track data from nearby basement outcrops in Aïr (Fig. 1; Cavellec, 2006) yield a central age of $44 \pm 2.6 \mathrm{Ma}$, and linear cooling from peak temperatures $>100^{\circ} \mathrm{C}$ in the early Cenozoic was interpreted based on thermal history modelling. Fission-track data from Carboniferous-Permian outcrops near Arlit (Fig. 1; Meyer, 1990) also yield similar EoceneOligocene ages (41-28 Ma), but track length data were not available to constrain thermal history models. Roberts \& White (2010) also estimated that uplift of the Hoggar initiated during the Eocene based on modelling of longitudinal river profiles.

\section{NEW THERMOCHRONOLOGICAL DATA FROM THE ILLIZI BASIN}

\section{Data Collection and Methodology}

\section{Thermal Maturity}

Integration of thermal maturity and apatite fission-track data provides constraints on the maximum paleotemperature of the sedimentary fill, and the timing of the last major cooling event (e.g., Green \& Duddy, 2012 and references therein). Vitrinite and bitumen reflectance and Rock-Eval data was collected from a suite of drill cuttings from Well A in the Illizi Basin (Fig. 1) in order to constrain the thermal maturity and peak paleotemperatures of Silurian to Carboniferous strata in the study area. Reflectance data was measured by two different laboratories (KK: Keiraville Konsultants and EGS: Egs-ploration). No sample count exceeds 14 measurements due to limited sample volume, and hence maturity estimates derived from the reflectance data must be treated with some caution. Only samples with $>5$ measurements are 
161 have been included in the study (Table 1). Bitumen reflectance was converted to vitrinite 162 reflectance equivalent using a relationship from Schoenherr et al. (2007). The vitrinite 163 reflectance data (and equivalents) were converted to an indicative estimate of maximum paleo164 temperature using Easy\%Ro (Sweeney \& Burnham, 1990) and a fixed heating rate of $1{ }^{\circ} \mathrm{C} / \mathrm{Myr}$. 165 Rock-Eval pyrolysis data (Table 2) were screened according to the criteria of English et al. 166 (2015) and Peters \& Cassa (1994). The $\mathrm{T}_{\max }$ to vitrinite reflectance conversion was adopted from 167 Jarvie et al. (2001) and Peters et al. (2005).

168

169

170

171

172

173

174

175

176

177

178

179

180

181

182

183

184

185

186

187

188

Apatite Fission-Track

Ten sandstone-bearing intervals in Well A, ranging in age from Carboniferous (Namurian) to Ordovician, were also sampled for apatite-fission track analysis. Fission-track analysis was carried out by Geotrack International according to the sample preparation details described by Green (1986). Fission-track ages were determined by the external detector method (Gleadow, 1981) with zeta calibration (Hurford \& Green, 1983) using dosimeter glass CN5 and a zeta of $392.9 \pm 7.4$ (analyst MEM - Geotrack International). Inverse modelling of the apatite fissiontrack data was utilised to constrain the range of possible time-temperature histories that are consistent with the measured data, and in particular to constrain (a) the timing and magnitude of maximum paleotemperature and (b) the timing and magnitude of the last major cooling event. Inverse modelling was carried out in HeFTy v.1.8.2 (Ketcham, 2005) using the annealing kinetic model of Ketcham et al. (2007). Chlorine content (wt.\%) was used as the kinetic parameter, and due to the generally low $\mathrm{Cl}$ contents $(<0.5 \mathrm{wt} . \%)$, each sample was modelled as a single population. C-axis projection was not used. The inverse models were run until 10,000 good paths were found. An acceptable and a good path were defined as having a goodness-of-fit (GOF) of $>$ 0.05 and $>0.5$ respectively according to the Kolmogorov-Smirnov test.

\section{Results}

Well A in the Illizi Basin penetrated $2118 \mathrm{~m}$ of Paleozoic stratigraphy ranging in age from Carboniferous (Namurian) to Ordovician. The results of the thermal maturity and apatite fissiontrack analysis are displayed in Tables 1-3 and graphically in Figure 2. The complete apatite fission-track dataset can be accessed in the Data Repository. The default profiles in Figure 2 
189

190

191

192

193

194

195

196

197

198

199

200

201

202

203

204

205

206

207

208

209

210

211

212

213

214

215

216

217

illustrate predicted thermal maturity and apatite fission-track age if no additional burial is assumed.

\section{Thermal Maturity}

From the thermal maturity data (Fig. 2a), it is readily apparent that measured peak maturity values are consistently higher than what would be predicted from the present-day burial depth (the deposition of the preserved stratigraphy alone). The slope of the default maturity profile is broadly similar to the measured peak maturity profile, suggesting that the peak paleogeothermal gradient is likely similar to the present-day geothermal gradient. These observations confirm that this sedimentary sequence has been subjected to higher temperatures in the past, likely due to deeper burial, and that significant exhumation of the basin has occurred.

\section{Apatite Fission-Track}

The ten sandstone samples for fission-track analysis were derived from a limited volume of drill cuttings. Two of the samples yielded no apatite grains and the apatite yield was generally moderate in the other eight samples (grain counts ranged between 6 and 21). The $\mathrm{P}\left(\chi^{2}\right)$ test was applied to all samples, using a probability $>5 \%$ as indicative of a homogeneous population (Galbraith, 1981). One sample (GC1085-3) produced a limited amount of data which failed the $\mathrm{P}\left(\chi^{2}\right)$ test, and is therefore excluded from further analysis here. Minor filtering in four of the remaining seven samples removed occasional spurious apatite grains with outlier chlorine contents or outlier fission track ages that appear to represent contamination. A summary of the final filtered dataset is presented in Table 3, but the data from the excluded grains from samples GC1085-2, GC1085-6, GC1085-7 and GC1085-8 are also provided in the Data Repository for completeness. The presented fission-track ages are pooled ages commonly used when $\mathrm{P}\left(\chi^{2}\right)>$ $5 \%$ (Galbraith \& Laslett, 1993). The two samples with $\mathrm{P}(\chi 2)<5 \%$ have central ages of $29.7 \pm 5.9$ Ma (GC1085-7) and 8.5 $\pm 2.4 \mathrm{Ma}(G C 1085-10)$. Only GC1085-1 (Namurian) provided sufficient track length measurements $(>100)$ to define a statistically meaningful track length distribution.

The measured apatite fission-track ages (Fig. 2b) for all samples, including the Carboniferous (Namurian) sample from a depth of only $180 \mathrm{~m}$, are younger than their corresponding depositional ages, indicating that fission-track annealing has affected the entire preserved stratigraphic sequence, with increased annealing in deeper samples that have been 
218 exposed to higher temperatures. The default profile illustrates the modelled vertical profile of 219 apatite fission-track age assuming no additional burial beyond that preserved today. As chlorine 220 content has been demonstrated to exert a systematic influence on annealing rates (Gleadow \& 221 Duddy, 1981; Green et al., 1985, 1986), a fixed chlorine content of $0.1 \mathrm{wt} . \%$ has been assumed 222 for the purposes of generating a vertical profile. Of the 93 apatite grains included in the analysis, $22380 \%$ have chlorine contents less than or equal to $0.1 \mathrm{wt} . \%$, and the average chlorine content is 2240.07 wt.\%. The default profile shows a characteristic "break-in-slope" (Fitzgerald \& Gleadow, 225 1988, 1990; Fitzgerald et al., 1995; Green \& Duddy, 2012) between present-day temperatures of $226 \sim 60$ and $90^{\circ} \mathrm{C}$, while total annealing is expected below $\sim 110^{\circ} \mathrm{C}$. The measured fission-track ages 227 are routinely younger than the default profile, indicating this stratigraphic sequence has 228 experienced hotter temperatures in the past. Samples from below $\sim 1,000 \mathrm{~m}$ depth (Devonian, 229 Silurian and Ordovician) are interpreted to have been totally annealed in the past (maximum 230 temperatures $>110^{\circ} \mathrm{C}$ ). Sixty-six apatite grains were analysed in these deeper samples (GC1085231 6, GC1085-7, GC1085-8, GC1085-9, GC1085-10) yielding fission-track ages ranging from 73-0 232 Ma with an average of $17 \mathrm{Ma}$ (see Data Repository); 96\% of these grains yielded Eocene and 233 younger fission-track ages. The shallower Carboniferous samples have only been partially 234 annealed, and the fission-track age bears no relation to any specific thermal event.

\section{Inverse Modelling of the Fission-Track Data}

236 Inverse modelling was carried out in HeFTy to constrain the range of possible time237 temperature histories that are consistent with the measured fission-track data (Ketcham, 2005). 238 The initial (deposition) and final (present-day) conditions were defined in the model set-up, and 239 additional constraint boxes were placed in temperature-time (T-t) space such that the inverse 240 models would honour our general understanding of the burial history of the basin - i.e., pre241 Hercynian burial, Hercynian exhumation, and post-Hercynian burial. Hercynian exhumation is 242 modelled to be consistent with the maximum preserved thicknesses of Carboniferous strata in the 243 eastern Illizi Basin (Galeazzi et al., 2010) and the Hercynian subcrop patterns observed 244 immediately to the north of the study area (English et al., 2016). Straight-line segments were 245 modelled between the constraint boxes such that the inverse modelling would identify a series of 246 relatively simple thermal histories that honour the fission-track data. The primary objective of 247 the inverse modelling was to identify what constraints can be placed on the timing and 
magnitude of maximum paleotemperature and also the timing and magnitude of the last major cooling event. Sample GC1085-1 (Namurian) was selected for inverse modelling as this sample passed the $\mathrm{P}\left(\chi^{2}\right)$ test $(11.7 \%)$ and provided the highest number of track length measurements (n $=106$ ). As the number of measured track lengths is more limited in the deeper samples (Table 3 ), it was elected to combine the Devonian and Silurian samples GC1085-6, GC1085-7 and GC1085-8 to provide a more statistically meaningful sample set $(\mathrm{n}=41)$ for inverse modelling. These samples were selected because they are from a narrow depth range (1385-1560 m), are at the lower temperature end of samples that have been fully annealed in the past $\left(76-82^{\circ} \mathrm{C}\right.$ presentday), and the combined fission-track age dataset also passes the $\mathrm{P}\left(\chi^{2}\right)$ test $(5.2 \%)$.

\section{Namurian Sample GC1085-1}

The inverse modelling results for sample GC1085-1 (Namurian) are presented in Figure 3a. The assumed timing constraints for the inverse modelling of this sample are as follows:

- A pre-deposition constraint (400-325 Ma) to account for inherited grains.

- The depositional constraint was set to approximate Namurian age (325-315 Ma) at 15$25^{\circ} \mathrm{C}$ surface temperature.

- The post-deposition constraints were defined on the basis of preserved stratigraphy and regional stratigraphic observations, and assume pre-Hercynian burial (300-260 Ma), Hercynian exhumation (260-160 Ma), and post-Hercynian reburial (180-0 Ma).

- Finally, the present-day temperature, based on downhole gauge temperature data from the well, defined the terminal conditions of the model.

The model was run until 10,000 good paths were identified. The vertices of the good paths $(\mathrm{GOF}>0.5)$ are highlighted in purple, while the vertices of the acceptable paths $(\mathrm{GOF}>0.05)$ are highlighted in green. The cloud of good path vertices during post-Hercynian reburial indicates that the maximum paleotemperature of the Namurian sample is likely to be in the 60$80^{\circ} \mathrm{C}$ range. Higher peak temperatures are allowable if maximum burial occurred during the Late Jurassic or Cretaceous as opposed to the Cenozoic (Fig. 3a). Hence, inverse modelling of the Namurian sample confirms that these strata reached maximum temperatures $\sim 30-50^{\circ} \mathrm{C}$ higher than present-day, but does not provide clear constraints on the timing of maximum burial. The 
276

277

278

279

280

281

282

283

284

285

286

287

288

289

290

291

292

293

294

295

296

297

298

299

300

301

302

303

best-fit of all the inverse model solutions is highlighted by the black line in the thermal history plot and reflects cooling from maximum temperatures in the Eocene (Fig. 3a). This inverse model solution provides a goodness-of-fit of 0.98 and 0.97 for the fission-track age and track length distribution respectively. This solution is non-unique and simply represents the best-fit of 10,000 different thermal histories that can provide a good fit to the measured data.

Silurian-Devonian Combined Sample GC1085-6,-7,-8

The inverse modelling results for the deeper combined samples GC1085-6, GC1085-7 and GC1805-8 (Devonian-Silurian) are presented in Figure 3b. The assumed timing constraints for the inverse modelling of this sample are as follows:

- A depositional constraint (423-400 Ma) at $5-15^{\circ} \mathrm{C}$ surface temperature. A predepositional constraint to allow for inherited grains is not required here as these samples have been fully annealed during burial.

- The post-deposition constraints were defined on the basis of preserved stratigraphy and regional stratigraphic observations, and assume pre-Hercynian burial (300-260 Ma), Hercynian exhumation (260-160 Ma), and post-Hercynian reburial (180-0 Ma).

- The present-day temperature defined the terminal conditions of the model.

- In addition, two cooling constraint boxes were added from 140-0 Ma at temperature intervals of $90-100^{\circ} \mathrm{C}$ and $70-85^{\circ} \mathrm{C}$. These boxes are intermediate steps between postHercynian reburial and present-day conditions, but serve to capture the constraints that the fission-track data can place on the timing of cooling into the partial annealing zone during the latest phase of exhumation.

The model was again run until 10,000 good paths were identified. The cloud of purple good-path vertices (Fig. 3b) during post-Hercynian reburial confirms that the apatite fission-track data cannot provide any constraints on the thermal history above $110^{\circ} \mathrm{C}$ (due to total annealing), except confirming that cooling from maximum temperatures had to initiate before $\sim 30 \mathrm{Ma}$. The cloud of good path vertices in the $90-100^{\circ} \mathrm{C}$ constraint box indicates that cooling through this temperature range likely occurred no earlier than $\sim 50 \mathrm{Ma}$ and no later than $\sim 10 \mathrm{Ma}$ - most likely during the 35-20 Ma window. Finally, the cloud of good path vertices in the $70-85^{\circ} \mathrm{C}$ constraint 
304

305

306

307

308

309

310

311

312

313

314

315

316

317

318

319

320

321

322

323

324

325

326

327

328

329

330

331

332

box indicates that these samples reached temperatures close to present-day no earlier than $\sim 30$ Ma. Hence, inverse modelling of the Devonian-Silurian combined sample confirms that these strata reached higher temperatures in the total annealing zone in the past, and cooled by $>20^{\circ} \mathrm{C}$ during the Eocene or later to reach their present-day temperatures. The best-fit of all the inverse model solutions is highlighted by the black line in the thermal history plot and reflects cooling from maximum paleotemperatures in the Eocene (Fig. 3b). This inverse model solution provides a goodness-of-fit of 0.98 and 0.99 for the fission-track age and track length distribution respectively. This solution is non-unique and simply represents the best-fit of 10,000 different thermal histories that can provide a good fit to the measured data.

\section{$\underline{\text { Summary }}$}

The inverse modelling confirms that deeper burial and hotter temperatures occurred in the study area in the past. The inverse modelling of the Namurian samples indicates maximum paleotemperatures $\sim 30-50^{\circ} \mathrm{C}$ higher than present-day at some point during the Late Jurassic to Cenozoic (Fig. 3a). The inverse modelling of the deeper Devonian-Silurian samples indicates that at least $20^{\circ} \mathrm{C}$ of cooling occurred during the Eocene or later (Fig. 3b). Two main candidate tectonic events could have led to cooling from maximum burial temperature in this region (Galeazzi et al., 2010). Model 1 is that exhumation from maximum burial conditions occurred during the Cenozoic and is related to uplift of the Hoggar Massif to the south of the study area. Model 2 is that exhumation from maximum burial conditions occurred during the Middle Cretaceous and is related to possible uplift associated with the Austrian tectonic event. Model 2 would still require some Cenozoic cooling to honour the fission-track data from the deeper samples (Fig. 3b).

\section{D BURIAL HISTORY MODELLING}

1D burial and thermal history modelling for Well A was carried out using the Genesis software (developed by Zetaware). Inputs for the thicknesses and lithologies of preserved and missing/eroded stratigraphy, present-day temperatures, and thermal maturity were based on well data and regional stratigraphic analysis (English et al., 2016). The youngest preserved stratigraphy in Well A is Carboniferous, and missing/eroded stratigraphy assumptions were 
333 reconstructed from younger preserved strata documented elsewhere in the Illizi and Berkine 334 basins (Turner et al., 2001; Yahi et al., 2001; Makhous \& Galushkin, 2003; Turner \& Sherif, 335 2007; Underdown et al., 2007; Dixon et al., 2010, Galeazzi et al., 2010) and in outcrops 336 (Swezey, 2009). Paleobathymetry was based on well-derived depositional facies and data from 337 Yahi et al. (2001) from the Berkine Basin. The onset of post-Hercynian deposition in the study 338 area is interpreted to have occurred in the Early Jurassic based on observed depositional edges 339 within the Illizi Basin (Fig. 1). Paleolatitudes were used to approximate the paleo-surface 340 temperature (Wygrala, 1989; Underdown, 2006).

341 Measured temperatures in Well A and 10 nearby wells indicate an average present-day 342 geothermal gradient of $38^{\circ} \mathrm{C} / \mathrm{km}$ (range $36-41^{\circ} \mathrm{C} / \mathrm{km}$ ), assuming an annual surface temperature 343 of $22^{\circ} \mathrm{C}$. The peak paleogeothermal gradient in the area is estimated to be $\sim 37^{\circ} \mathrm{C} / \mathrm{km}$ based on 344 available thermal maturity data (English et al., 2016). The calculated present-day basal heat flow 345 is $65 \mathrm{~mW} / \mathrm{m}^{2}$, which is consistent with documented heat flows in the southern Illizi Basin (60 $346100 \mathrm{~mW} / \mathrm{m}^{2}$; Lesquer et al., 1990). The basal heat flow was held constant through time in the 347 Genesis models due to: (a) the similarity between the present-day geothermal gradient $348\left(38^{\circ} \mathrm{C} / \mathrm{km}\right)$ and peak paleogeothermal gradients during maximum burial $\left(\sim 37^{\circ} \mathrm{C} / \mathrm{km}\right)$, and (b) the 349 absence of any major rifting event in the vicinity. Variations in heat flow have been assumed in 350 some other studies in North Africa, such as in the Ahnet and Reggane basins (Fig. 1), where peak 351 temperatures are related to a brief 'heat spike' or thermal anomaly at $\sim 200 \mathrm{Ma}$, characterized by 352 high peak paleogeothermal gradients $\left(\sim 60-80^{\circ} \mathrm{C} / \mathrm{km}\right.$; Logan \& Duddy, 1998) that are not 353 observed in our Illizi Basin dataset.

354 Two independent 1D burial and thermal history models for Well A were constructed (Fig. 355 4) - one with maximum burial during the Cenozoic (Model 1) and one with maximum burial 356 during the Middle Cretaceous (Model 2). Both thermal history models honour the preserved 357 stratigraphy at Well A and the present-day temperature data. The post-Namurian depositional 358 and erosional history was adjusted to calibrate to the available thermal maturity and apatite 359 fission-track age data (Fig. 2). The modelled temperature-time (T-t) pathways for each layer in 360 Genesis were imported into HeFTy, and a fixed chlorine content of $0.1 \mathrm{wt} . \%$ has been assumed 361 for the purposes of generating a vertical profile of fission-track age for both Model 1 and Model 362 (Fig. 2b). These two vertical profiles are practically indistinguishable from each other, predict 
363 a "break-in-slope" at much shallower depths than the default profile, and are more consistent 364 with the measured fission-track age data. There is a small discrepancy in the shallower samples 365 between the measured fission-track ages and the continuous profiles, and this may be because of 366 (1) inherited tracks within these partially annealed grains or (2) a slightly higher $\mathrm{Cl}$ content. For 367 example, the analysed grains in the shallowest Namurian sample have an average $\mathrm{Cl}$ content of $3680.16 \mathrm{wt} . \%$, and the modelled fission-track age for the actual grain population (blue squares 369 Model 1; red squares - Model 2) plots closer to the measured fission-track age (red circle) than 370 the continuous profile assuming $0.1 \mathrm{wt} . \% \mathrm{Cl}$. Finally, both Model 1 and Model 2 were calibrated 371 to the fission-track age and track length distributions for Namurian sample (GC1085-1) and the 372 combined Devonian-Silurian samples (GC1085-6, GC1085-7 and GC1085-8) via forward 373 modelling of the associated T-t pathway in HeFTy. The forward modelling results for Model 1 374 and Model 2 are displayed in Figures 5 and 6 respectively. The goodness-of-fit (GOF) is greater 375 than 0.85 in all cases except for the fission-track age in the Namurian sample where pre376 depositional inheritance may be the cause of some additional variation.

377 Model 1 assumes additional post-Hercynian sedimentary burial throughout the Mesozoic 378 with maximum burial in the Early Eocene (52 Ma), followed by $(\sim 1 \mathrm{~km})$ exhumation during the 379 Eocene-Miocene (Fig. 4a). Minor mid-Aptian exhumation ( $\sim 25 \mathrm{~m})$ is also included in this model 380 to represent the Austrian unconformity. Model 2 assumes that maximum temperature occurs 381 during the Aptian (124 Ma) followed by $\sim 570 \mathrm{~m}$ of Austrian exhumation, with renewed Late 382 Cretaceous and early Cenozoic burial, and $\sim 840 \mathrm{~m}$ exhumation initiating during the Eocene (Fig. $3834 \mathrm{~b}$ ). Both Model 1 and Model 2 honour the apatite fission-track and thermal maturity data for 384 Well A (Figs. 2, 5 and 6).

\section{TIMING OF MAXIMUM BURIAL IN THE ILLIZI BASIN}

In the Illizi Basin, deformation and erosion associated with the Austrian tectonic event has been focussed along the north-south Amguid-El Biod fault trend at the western margin of the basin (Galeazzi et al., 2010), while the more central parts of the Illizi Basin show less effect. 
392

393

394

395

396

397

398

399

400

401

402

403

404

405

406

407

408

409

410

411

412

413

414

415

416

417

418

419

420

comment with certainty on the magnitude of the Austrian erosional event due to the lack of sedimentary record. However, $\sim 80 \mathrm{~km}$ north-northwest of Well A, pre- and post-Austrian strata at the Tin Fouyé Tabankort field (Chiarelli et al., 1978; Fig. 1) do not display any significant angular discordance and are uniformly tilted northward together by a younger event. Based on this evidence, the preferred model for the study area involves maximum burial during the Cenozoic followed by exhumation and cooling in the Eocene-Miocene (Model 1). While the Mesozoic portion of the modelled thermal history solution is non-unique (i.e., Model 2 is also a possible valid model), the new dataset does require significant $(0.5-1.0 \mathrm{~km})$ Cenozoic exhumation in the study area to match the uniformly young fission-track ages in the deeper samples (e.g., Fig. 3b). The timing of the end of the exhumation cannot be definitively resolved, but a good fit to the fission-track data was achieved with significant exhumation ending during the Miocene. In the preferred Model 1, the total amount of Cenozoic exhumation at Well A in the Illizi Basin is estimated at $\sim 1.0-1.1 \mathrm{~km}$.

\section{GEOMETRY AND MAGNITUDE OF HOGGAR UPLIFT AND EXHUMATION}

\section{Comparison with Regional Thermochronological Data}

Previous apatite fission-track data over the Hoggar have provided widespread Mesozoic ages (Carpena et al., 1988). New apatite fission-track data presented in this study from the Illizi Basin support other recent apatite (U-Th)/He thermochronologic data (Rougier et al., 2013) and inverse modelling of longitudinal river profiles (Roberts \& White, 2010), which indicate that the last major exhumation phase initiated during the Eocene. Rougier et al. (2013) reported apatite (U-Th)/He data from exposed basement samples adjacent to the Lower Cretaceous Serouenout deposits (Fig. 1), and interpreted that these rocks underwent post-depositional heating to 60$80^{\circ} \mathrm{C}$, corresponding to $1-3 \mathrm{~km}$ of additional burial (assuming an Eocene geothermal gradient of $22-28^{\circ} \mathrm{C} / \mathrm{km}$ and surface temperatures of $15-30^{\circ} \mathrm{C}$ ), prior to exhumation. Using the maximum burial conditions assumed at Well A in the Illizi Basin (i.e., Eocene geothermal gradient of 36$41^{\circ} \mathrm{C} / \mathrm{km}$ and surface temperature of $24^{\circ} \mathrm{C}$ ), exhumation in the Serouenout area would correspond to $\sim 0.9-1.6 \mathrm{~km}$. It is possible that previously published Mesozoic apatite fission-track ages from outcrop samples of the Hoggar Massif (Carpena et al., 1988) were only partially 
421 annealed during subsequent Mesozoic-Cenozoic reburial, and hence the fission-track ages may 422 not directly relate to any specific thermal event.

423 South of the Hoggar, in the Arlit area of Niger (Fig. 1), vitrinite reflectance and Rock-Eval 424 pyrolysis data from the Carboniferous (Visean) Guézouman/Tarada Formation in the Tim Mersoï 425 Basin indicate a thermal maturity of $0.66 \mathrm{R}_{\mathrm{o}} \%$ and a $\mathrm{T}_{\max }$ of $434^{\circ} \mathrm{C}$ at $\sim 100 \mathrm{~m}$ depth (sample 426 927/607; Forbes et al., 1988). These measurements correspond to an estimated peak temperature 427 of $\sim 109^{\circ} \mathrm{C}$ using Easy\%Ro (Sweeney \& Burnham, 1990) and a fixed heating rate of $1^{\circ} \mathrm{C} / \mathrm{Myr}$. 428 Rock-Eval pyrolysis data from the same formation in the Akouta area (sample CMK5; Salze, 429 1998), screened according to the criteria of English et al. (2015), yield a $\mathrm{T}_{\max }$ of $430^{\circ} \mathrm{C}$, and an 430 equivalent $\mathrm{R}_{0} \%$ of $\sim 0.56$ corresponds to an estimated peak temperature of $\sim 95^{\circ} \mathrm{C}$. Using the 431 maximum burial conditions from Well A, these data suggest that the Visean formations reached 432 maximum burial depths of $\sim 1.7-2.3 \mathrm{~km}$ in the Tim Mersoï Basin. Apatite fission-track data from 433 nearby basement outcrops in Aïr (Cavellec, 2006; Fig. 1) yield a central age of $44 \pm 2.6 \mathrm{Ma}$ and 434 an average track length $12.56 \pm 0.22 \mu \mathrm{m}$. Based on thermal history modelling, Cavellec (2006) 435 interpreted a best-fit model with linear cooling from peak temperatures $>100^{\circ} \mathrm{C}$ in the early 436 Cenozoic. Fission-track data from Carboniferous-Permian outcrops near Arlit (Meyer, 1990) also 437 yield similar Eocene-Oligocene ages (41-28 Ma), but track length data were not available to 438 constrain thermal history models. Regionally, distinct Cenozoic exhumation has been interpreted 439 in fission-track studies across the Ahnet Basin (Logan \& Duddy, 1998), Tihemboka Arch 440 (Glover, 1999; Boote et al., 2012), and Al Qarqaf Arch (Underdown et al., 2007), with only 441 modest Cenozoic exhumation interpreted further north in the Berkine-Ghadames Basin 442 (Underdown et al., 2007) (Fig. 1).

443 In summary, these regional data confirm that a major Cenozoic cooling and exhumation 444 event extended across the Hoggar region and into the surrounding sedimentary basins to the 445 north and south. The preservation of a relatively complete Mesozoic-Cenozoic stratigraphic 446 sequence in both the Berkine Basin (Galeazzi et al., 2010) and the southern Iullemmeden Basin 447 (Zanguina et al., 1998) constrains the lateral extent of this exhumation event to the north and 448 south respectively.

449 Geometry of the Hoggar Uplift 
450 A regional schematic structural section has been constructed from the Berkine Basin in the 451 north, across the Hoggar Massif, to the Iullemmeden Basin to the south, to define the geometry 452 of the Hoggar uplift (Fig. 7). Following Rougier et al. (2013), we interpret that at least parts of 453 the Hoggar Massif endured significant post-Hercynian Mesozoic and early Cenozoic reburial, 454 although it remains unknown if this reburial affected the entire Hoggar region. Cenozoic rock 455 uplift occurred across the Hoggar swell and surrounding basins over a distance $>1,500 \mathrm{~km}$ from 456 north to south, and uplift magnitudes within the core of the swell are in excess of $2 \mathrm{~km}$ (Fig. 7). 457 These uplift estimates are consistent with $\sim 1 \mathrm{~km}$ post-depositional burial of the Serouenout 458 sandstones (at lower elevations), followed by uplift to their present-day elevations. Uplift 459 magnitudes may be even greater in some local areas of the Hoggar such as Atakor (off-section 460 from Fig. 7) where the Precambrian basement reaches elevations of $\sim 2,400 \mathrm{~m}$ a.s.1. (Girod, 461 1971). Within the adjoining sedimentary basins, the magnitude of exhumation is interpreted to 462 increase from the flanks towards the central part of the Hoggar uplift. The reduction in erosion 463 within the core of the Hoggar (Fig. 7) may be due to the presence of more resistant crystalline 464 basement compared to the sedimentary strata, or due to a reduction in fluvial erosion rates due to 465 a smaller drainage area and lower discharge rates.

\section{Driving Mechanisms for Uplift}

467 The driving mechanisms for uplift of the Hoggar swell have been the subject of much 468 debate (Liégeois et al., 2005). A deep-mantle plume origin has been previously discounted based 469 on the lack of an associated present-day thermal anomaly (Lesquer et al., 1988; 1989), and the 470 absence of expected evidence along the plate's projected path since $35 \mathrm{Ma}$ (Liégeois et al., 471 2005). As an alternative, Liégeois et al. (2005) proposed that edge-driven convection (King \& 472 Anderson, 1998), associated with changes in lithospheric thickness beneath the shield, may have 473 facilitated asthenospheric mantle uprising and decompression melting during Eocene-Recent 474 reactivation of Pan-African basement structures, linked to Africa-Eurasia collision to the north. 475 Moucha \& Forte (2011) and Jones et al. (2012) have both interpreted dynamic support for the 476 Hoggar swell, indicating a role for underlying mantle convection. The data presented here 477 indicates that the initiation of Cenozoic exhumation in the Illizi Basin, on the northern flank of 478 the Hoggar swell, is coincident with the onset of intra-plate volcanism across a number of other 479 North African magmatic provinces, including the Tibesti and Darfur districts (Wilson \& 
480

481

482

483

484

485

486

487

488

489

490

491

492

493

494

495

496

497

498

499

500

501

502

503

504

Guiraud, 1992; Wilson et al., 1998; Liégeois et al., 2005; Fig. 1), and is broadly co-eval with the onset of Africa-Eurasia collision during the Mid-Late Eocene (e.g. Frizon de Lamotte et al., 2011). This collisional event resulted in inversion along the northwestern Atlas zone (Fig. 1), and concomitant minor angular unconformities can be observed in many North African sedimentary basins (e.g. Berkine, Oued Mya and Iullemmeden basins; Guiraud et al., 2005; Lang et al., 1990). However, the relationship between the Atlas event and the Hoggar uplift still remains unclear. Deposition of Upper Eocene-Pliocene sediments (the "Continental Terminal") across Saharan Africa (Kilian, 1931) may represent the onset of clastic sedimentation derived from the growing intracratonic swells, and the uplifting Atlasic belt to the north. Additionally, based on detrital zircon age-dating, the Hoggar region has been proposed as one of the possible source regions of reworked Oligocene to Miocene clastics of the Numidian Flysch deposited in the western Mediterranean (Thomas et al., 2010).

\section{CONCLUSIONS}

This study quantifies the magnitude and timing of kilometre-scale uplift and exhumation of the Illizi Basin on the northern margin of the Hoggar swell. Integration with regional data indicates that the Cenozoic uplift event in the Hoggar region extended over a distance in excess of $1,500 \mathrm{~km}$ from north to south into the flanking basins, and the magnitude of rock uplift in the core of the swell is estimated to be in excess of $2 \mathrm{~km}$. The timing of Cenozoic uplift is broadly coincident with magmatism on the Hoggar and other North African magmatic provinces, and with the onset of tectonic compression in the Atlasic belt to the north. Thermal history studies in sedimentary basins flanking other North African Cenozoic highs would help to constrain the true geometry and timing of these enigmatic rock uplifts, and help to unravel the continental-scale lithospheric and sub-lithospheric processes behind their genesis. 


\section{ACKNOWLEDGMENTS}

506 We thank Petroceltic International, Sonatrach and Enel, for sponsoring this study and granting 507 permission for publication. Additionally, we gratefully acknowledge Zhiyong He and Rich 508 Ketcham for the generous donations of the Genesis and HeFTy software for this research. This 509 manuscript has also benefitted from input by Dermot Corcoran, Sean McDade, Ian Duddy, 510 Lorraine Eglinton and Sabine Cavellec in particular, and from constructive feedback from Cindy 511 Ebinger, Yves Missenard and two anonymous reviewers. We also gratefully acknowledge 512 Richard Dixon and Jake Hossack for sharing some of their insights on the evolution of the 513 Hoggar swell.

514

515 CONFLICT OF INTEREST

516 No conflict of interest declared.

517 
518

519

520

521

522

523

524

525

526

527

528

529

530

531

532

533

534

535

536

537

538

539

540

541

542

543

\section{REFERENCES}

Acheche, M.H., M'Rabet, A., Ghariani, H., Ouahchi, A. \& Montgomery, S.L. (2001) Ghadames basin, southern Tunisia: A reappraisal of Triassic reservoirs and future prospectivity. AAPG Bull., 85, 765-780.

Aït Hamou, F., Dautria, J.M., Cantagrel, J.M., Dostal, J. \& Briqueu, L. (2000) Nouvelles données géochronologiques et isotopiques sur le volcanisme cénozoïque de l'Ahaggar (Sahara algérien): Des arguments en faveur d'un panache. Comptes Rendus de l'Académie des Sciences de Paris, 330, 829-836.

Al-HaJRI, Y., White, N. \& Fishwick, S. (2009) Scales of transient convective support beneath Africa. Geology, 37, 883-886.

Aliev, M., Aït laoussine, N., Avrov, V., Aleksine, G., Barouline, G., Lakovlev, B., Korj, M., Kouvykine, J., Makarov, V., Mazanov, V., Medvedev, E., Mkrtchiane, O., Moustafinov, R., Oriev, L., Oroudjeva, D., Oulmi, M. \& SAÏD, A. (1971) Geological structures and estimation of oil and gas in the Sahara in Algeria. Altamira-Rotopress, S.A., Spain, $265 \mathrm{pp}$.

Azzouni-Sekkal, A., Bonin, B., Benhallou, A., Yahiaoui, R. \& Liégeois, J.P. (2007) Cenozoic alkaline volcanism of the Atakor massif, Hoggar, Algeria. In: Cenozoic volcanism in the Mediterranean area (Ed. by L. Beccaluva, G. Bianchini \& M. Wilson), Geol. Soc. Am. Spec. Paper, 418, 321-340.

Beccaluva, L., Azzouni-Sekkal, A., Benhallou, A., Bianchini, G., Ellam, R.M., Marzola, M., SienA, F. \& STUART, F.M. (2007) Intracratonic asthenosphere upwelling and lithosphere rejuvenation beneath the Hoggar swell (Algeria): Evidence from HIMU metasomatised lherzolite mantle xenoliths. Earth Planet. Sci. Lett., 260, 482-494.

Beuf, S., Biju-Duval, B., de Charpal, O., Rognon, P., Gariel, O. \& Bennacef, A. (1971) Les grès du Paléozoïque inférieur au Sahara. Publications de l'Institut Français du Pétrole, Coll. Science et Technique du Pétrole 18, Paris, 464 pp. 
544 Boote, D. (2013) The 'Austrian Event' of the Afro-Arabian Plate and its influence upon 545 Cretaceous petroleum systems. AAPG European Regional Conference, Barcelona, Spain, April $546 \quad 8-10,2013$.

547 Boote, D.R.D., Clark-Lowes, D.D. \& Traut, M.W. (1998) Palaeozoic petroleum systems of 548 North Africa. In: Petroleum geology of North Africa (Ed. by D.S. MacGregor, R.T.J. Moody \& 549 D.D. Clark-Lowes), Geol. Soc. Lond., Spec. Publ., 132, 7-68.

550 Boote, D.R.D., Dardour, A., Green, P.F., Smewing, J.D. \& van Hoeflaken, F. (2012) 551 Burial and unroofing history of the base Tanezzuft 'hot' shale source rock, Murzuk basin, SW 552 Libya: New AFTA constraints from basin margin outcrops. Geol. South. Libya, 2, 21-36.

553 Bordet, P. (1954) La série de Serouenout (Ahaggar oriental) est d'âge "Continental 554 Intercalaire" (Crétacé Moyen). Comptes Rendus de l'Académie des Sciences, 238, 500-503.

555 BraUn, J. (2010) The many surface expressions of mantle dynamics. Nature Geosc., 3, 825-833.

556 Burke, K. (1996) The African plate. South Afr. J. Geol., 99, 341-409.

557 Burke, K. \& GunNell, Y. (2008) The African erosion surface: A continental-scale synthesis of 558 geomorphology, tectonics and environmental change over the past 180 million years. Geological 559 Society of America Memoirs, 201, 1-66.

560 Burollet, P., Mugniot, J. \& Sweeney, P. (1978) The geology of the Pelagian block: the 561 margins and basins off southern Tunisia and Tripolitania. In: The Western Mediterranean (Ed. 562 by A. Nairn, W. Kanes \& F. Stehli), The Ocean Basins and Margins, Springer, 331-359.

563 Busson, G., Dhondt, A., Amédro, F., Néraudeau, D. \& Cornée, A. (1999) La grande 564 transgression du Cénomanien supérieur-Turonien inférieur sur la Hamada de Tinrhert (Sahara 565 algérien): Datations biostratigraphiques, environnement de dépôt et comparaison d'un témoin 566 épicratonique avec les séries contemporaines à matière organique du Maghreb. Cret. Res., 20, $567 \quad 29-46$.

568 Carpena, J., Kienast, J., Ouzegane, K. \& Jehanno, C. (1988) Evidence of the contrasted 569 fission track clock behavior of the apatites from In Ouzzal carbonatites (northwest Hoggar): The 570 low-temperature thermal history of an Archean basement. Geol. Soc. Am. Bull., 100, 1237-1243. 
571 Cavellec, S. (2006) Evolution diagénétique du basin de Tim Mersoï et conséquences pour la 572 génèse des minéralisations uranifères dans les formations carbonifères du Guezouman et du 573 Tarat (district Arlit-Akokan, Niger). PhD thesis, Université du Paris-Sud, Paris, France.

574 Choubert, A. \& Faure-Muret, A. (1990) International geological map of Africa. CGMW 575 (Commission of the Geological Map of the World), UNESCO, Paris, France, scale 1:5,000,000, 5766 sheets.

577 DAUTRIA, J.M. \& LeSQUeR, A. (1989) An example of the relationship between rift and dome: 578 recent geodynamic evolution of the Hoggar Swell and of its nearby regions (Central Sahara, 579 Southern Algeria and Eastern Niger). Tectonophysics, 163, 45-61.

580 Dixon, R.J., Moore, J.K.S., Bourne, M., Dunn, E., Haig, D.B, Hossack, J., Roberts, N., 581 PARSONS, T. \& SiMMONS, C.J. (2010) Integrated petroleum systems and play fairway analysis in 582 a complex Palaeozoic basin: Ghadames-Illizi Basin, North Africa. In: Petroleum geology: From 583 mature basins to new frontiers (Ed. by B.A. Vining \& S.C. Pickering), Geol. Soc. Lond., Petrol. 584 Geol. Conf. Series, 7, 735-760.

585 England, P. \& Molnar, P. (1990) Surface uplift, uplift of rocks, and exhumation of rocks. 586 Geology, 18, 1173-1177.

587 English, J.M., LunN, G.A., FerreIRA, L. \& YACU, G. (2015) Geologic evolution of the Iraqi 588 Zagros, and its influence on the distribution of hydrocarbons in the Kurdistan region. $A A P G$ 589 Bull., 99, 231-272.

590 English, K.L., Redfern, J., Corcoran, D.V., English, J.M. \& Yahia Cherif, R. (2016) 591 Constraining burial history and petroleum charge in exhumed basins: new insights from the Illizi 592 Basin, Algeria. AAPG Bull., 100, XXX-XXX.

593 FABRE, J. (1976) Introduction à la géologie du Sahara algérien et des régions voisines. Sociétié 594 Nationale d'Édition et de Diffusion, Algiers, Algeria, 422 pp.

595 Fitzgerald, P.G. \& Gleadow, A.J.W. (1988) Fission-track geochronology, tectonics and 596 structure of the Transantarctic Mountains in Northern Victoria Land, Antarctica. Chem. Geol., $597 \quad 73,169-198$. 
598 FitzGerald, P.G. \& Gleadow, A.J.W. (1990) New approaches in fission track geochronology 599 as a tectonic tool: Examples from the Transantarctic Mountains. Nucl. Tracks Radiat. Meas., 17, $600 \quad 351-357$.

601 FitzGerald P.G., Sorkhabi, R.B., Redfield, T.F. \& Stump, E. (1995) Uplift and denudation of 602 the central Alaska Range: A case study in the use of apatite fission track thermochronology to 603 determine absolute uplift parameters. J. Geophy. Res., 100, 20175-20191.

604 Forbes, P., Landais, P., Bertrand, P., Brosse, E., Espitalié, J. \& Yahaya, M. (1988) 605 Chemical Transformations of Type-III Organic Matter Associated with the Akouta Uranium 606 Deposit (Niger): Geological Implications. Chem. Geol., 71, 267-282.

607 Frizon de Lamotte, D., Raulin, C., Mouchot, N., Wrobel-Daveau, J.C., Blanpied, C. \& 608 RingenBACH, J.C. (2011) The southernmost margin of the Tethys realm during the Mesozoic 609 and Cenozoic: Initial geometry and timing of the inversion processes. Tectonics, 30, TC3002.

610 Galbraith, R.F. (1981) On statistical models for fission-track counts. Math. Geol., 13, 471611478.

612 Galbraith, R.F. \& Laslett, G.M. (1993) Statistical models for mixed fission-track ages. Nucl. 613 Tracks Radiat. Meas., 21, 459-470.

614 Galeazzi, S., Point, O., Haddadi, N., Mather, J. \& Druesne, D. (2010) Regional geology 615 and petroleum systems of the Illizi-Berkine area of the Algerian Saharan Platform: An overview. 616 Mar. Petrol. Geol., 27, 143-178.

617 GeniK, G.J. (1993) Petroleum geology of Cretaceous-Tertiary rift basins in Niger, Chad, and 618 Central African Republic. AAPG Bull., 77, 1405-1434.

619 GIROD, M. (1971) Le massif volcanique de l'Atakor (Hoggar, Sahara Algérien). Étude 620 pétrographique, structurale et volcanologique. Centre de Recherches sur les Zones Arides, série 621 Géologie 12, Éditions du Centre National de la Recherche Scientifique, Paris, France, 158 pp.

622 Gleadow, A.J.W. (1981) Fission-track dating methods: What are the real alternatives? Nucl. 623 Tracks, 5, 3-14.

624 GLEADOW, A.J.W. \& DUdDY, I.R. (1981) Fission track analysis: a new tool for the evaluation of 625 thermal histories and hydrocarbon potential. Aust. Petrol. Expl. Assoc. J., 23, 93-102. 
626

627

628

629

630

631

632

633

634

635

636

637

638

639

640

641

642

643

644

645

646

647

648

649

650

651

Glover, R.T. (1999) Aspects of intraplate deformation in Saharan Cratonic Basins. PhD thesis, University of Wales, Aberystwyth, United Kingdom.

GrEen, P.F. (1986) On the thermo-tectonic evolution of Northern England: evidence from fission-track analysis. Geol. Mag., 123, 493-506.

GrEen, P. \& DudDY, I.R. (2012) Thermal history reconstruction in sedimentary basins using apatite fission-track analysis and related techniques. In: Analyzing the thermal history of sedimentary basins: Methods and case studies (Ed. by N.B. Harris \& K.E. Peters), Soc. Sed. Geol., Spec. Publ., 103, 65-104.

Green, P.F., Duddy, I.R., Gleadow, A.J.W., Tingate, P.R. \& Laslett, G.M. (1985) Fissiontrack annealing in apatite: track length measurements and the form of the Arrhenius plot. Nucl. Tracks, 10, 323-328.

Green, P.F., Duddy, I.R., Gleadow, A.J.W., Tingate, P.R. \& Laslett, G.M. (1986) Thermal annealing of fission tracks in apatite: 1. A qualitative description. Chem. Geol., 59, 237-253.

GuIRAUD, R. (1998) Mesozoic rifting and basin inversion along the northern African Tethyan margin: an overview. In: Petroleum geology of North Africa (Ed. by D.S. MacGregor, R.T.J. Moody \& D.D. Clark-Lowes), Geol. Soc. Lond., Spec. Publ., 132, 217-229.

Guiraud, R., Bosworth, W., Thierry, J. \& Delplanque, A. (2005) Phanerozoic geological evolution of northern and central Africa: An overview. J. Afr. Earth Sci., 43, 83-143.

Holmes, A. (1944) Principles of Physical Geology. Thomas Nelson \& Sons Ltd., Edinburgh, United Kingdom, 532 pp.

Hurford, A.J. \& Green, P.F. (1983) The zeta age calibration of fission-track dating. Chem. Geol., 41, 285-317.

Jarvie, D., Claxton, B., Henk, B. \& Breyer, J. (2001) Oil and shale gas from the Barnett Shale, Fort Worth Basin, Texas. AAPG Annual Meeting Program, 10, A100.

Jones, S.M., Lovell, B. \& Crosby, A.G. (2012) Comparison of modern and geological observations of dynamic support from mantle convection. J. Geol. Soc. Lond., 169, 745-758. 
652 KeTCHAM, R.A. (2005) Forward and inverse modeling of low-temperature thermochronometry 653 data. Rev. Min. \& Geochem., 58, 275-314.

654 Ketcham, R.A., Carter, A., Donelick, R.A., Barbarand, J. \& Hurford, A.J. (2007) 655 Improved modelling of fission-track annealing in apatite. Am. Mineralogist, 92, 799-810.

656 Kilian, C. (1931) Des principaux complexes continentaux du Sahara. Comptes Rendus 657 sommaire de la Societé Géologique de la France, 9, 109-111.

658 KInG, S.D. \& Anderson, D.L. (1998) Edge-driven convection. Earth Planet. Sci. Lett., 160, $659 \quad 289-296$.

660 KogBe, C.A. (1981) Cretaceous and Tertiary of the Iullemmeden Basin in Nigeria (West Africa). 661 Cret. Res., 2, 129-186.

662 Lang, J., Kogbe, C., Alidou, S., Alzouma, K.A., Bellion, G., Dubois, D., Durand, A., 663 Guiraud, R., Houessou, A., De Klasz, I., Romann, E., Salard-Cheboldaeff, M. \& 664 Trichet, J. (1990) The continental terminal in West Africa. J. Afr. Earth Sci., 10, 79-99.

665 LEFRANC, J.P. \& GUIRAUD, R. (1990) The continental intercalaire of northwestern Sahara and its 666 equivalents in the neighbouring regions. J. Afr. Earth Sci., 10, 27-77.

667 Lesquer, A., Bourmatte, A. \& Dautria, J.M. (1988) Deep structure of the Hoggar domal 668 uplift (central Sahara, south Algeria) from gravity, thermal and petrological data. 669 Tectonophysics, 152, 71-87.

670 Lesquer, A., Bourmatte, A., Ly, S. \& Dautria, J.M. (1989) First heat flow determination 671 from the Central Sahara: Relationship with the Pan-African belt and Hoggar domal uplift. J. Afr. 672 Earth Sci., 9, 41-49.

673 Lesquer, A., TAKherist, D., Dautria, J.M. \& Hadiouche, O. (1990) Geophysical and 674 petrological evidence for the presence of an "anomalous" upper mantle beneath the Sahara 675 basins (Algeria). Earth Planet. Sci. Lett., 96, 407-418.

676 Liégeois, J.P., Benhallou, A., Azzouni-Sekkal, A., Yahiaouni, R. \& Bonin, B. (2005) The 677 Hoggar swell and volcanism: Reactivation of the Precambrian Tuareg shield during Alpine 678 convergence and West African Cenozoic volcanism. In: Plates, plumes and paradigms (Ed. by 
679 G.R. Foulger, J.H. Natland, D.C. Presnall \& D.L. Anderson), Geol. Soc. Am. Spec. Paper, 388, $680379-400$

681 LOGAN, P. \& DudDY, I. (1998) An investigation of the thermal history of the Ahnet and Reggane

682

683

684

685

686

687

688

689

690

691

692

693

694

695

696

697

698

699

700

701

702

703

704 basins, central Algeria, and the consequences for hydrocarbon generation and accumulation. In: Petroleum geology of North Africa (Ed. by D.S. MacGregor, R.T.J. Moody \& D.D. ClarkLowes), Geol. Soc. Lond., Spec. Publ., 132, 131-155.

Makhous, M. \& GALushKin, Y.I. (2003) Burial history and thermal evolution of the northern and eastern Saharan basins. AAPG Bull., 87, 1623-1651.

MeYer, A.J. (1990) Les traces de fission dans l'apatite : Etude expérimentale et application à l'histoire thermique de bassins sédimentaires. PhD thesis, Institut National Polytechnique de Lorraine, Nancy, France.

MouchA, R. \& Forte, A.M. (2011) Changes in African topography driven by mantle convection. Nature Geosci., 4, 707-712.

PETERS, K.E. \& CASSA, M.R. (1994) Applied source rock geochemistry. In: The petroleum system - From source to trap (Ed. by L.B. Magoon \& W.G. Dow), AAPG Memoir, 60, 93-120.

Peters, K.E., Walters, C.C. \& Moldowan, J.M. (2005) The Biomarker Guide, Volume 1: Biomarkers and Isotopes in the Environment and Human History. Cambridge University Press, Cambridge, UK, 492 pp.

Philippe, M., Cuny, G., Bamford, M., Jaillard, E., Barale, G., Gomez, B., Ouaja, M., Thévenard, F., Thiébaut, M. \& Von Sengbusch, P. (2003) The palaeoxylological record of Metapodocarpoxylon libanoticum (Edwards) Dupéron-Laudoueneix et Pons and the Gondwana Late Jurassic-Early Cretaceous continental biogeography. J. Biogeog., 30, 389-400.

Roberts, G.G. \& White, N. (2010) Estimating uplift rate histories from river profiles using African examples. J. Geophys. Res., 115, B02406.

ROUGIER, S. (2012) Interactions lithosphere-asthenosphere et mouvements verticaux: Le cas du Massif du Hoggar. PhD thesis, Universite Paris-Sud, Paris, France. 
705 706 707 708 709 710 711 712 713 714 715 716 717 718 719 720 721

722 723 724

725 726 727 728 729

730 731 732

Rougier, S., Missenard, Y., Gautheron, C., Barbarand, J., Zeyen, H., Pinna, R., LiÉGeois, J.P., Bonin, B., OuABadi, A., El-Messaoud Derder, M. \& Frizon de LAMotte, D. (2013) Eocene exhumation of the Tuareg Shield (Sahara Desert, Africa). Geology, 41, 615-618.

SAHAGIAN, D. (1988) Epeirogenic motions of Africa as inferred from Cretaceous shoreline deposits. Tectonics, 7, 125-138.

SALZE, D. (2008) Etude des interactions entre uranium et composés organiques dans les systèmes hydrothermaux. PhD thesis, Université Henri Poincaré, Nancy, France.

Schoenherr, J., Littke, R., Urai, J., Kukla, P. \& Rawahi, Z. (2007) Polyphase thermal evolution in the Infra-Cambrian Ara Group (South Oman Salt Basin) as deduced by maturity of solid reservoir bitumen. Org. Geochem., 38, 1293-1318.

SwEENEY, J. \& BURNHAM, A. (1990) Evaluation of a simple model of vitrinite reflectance based on chemical kinetics. AAPG Bull., 74, 1559-1570.

Swezey, C.S. (2009) Cenozoic stratigraphy of the Sahara, Northern Africa. J. Afr. Earth Sci., 53, 89-121.

Thomas, M.F.H., Bodin, S., Redfern, J. \& Irving, D.H.B. (2010) A constrained African craton source for the Cenozoic Numidian Flysch: Implications for the paleogeography of the western Mediterranean basin. Earth Sci. Reviews., 101, 1-23.

Turner, P., Pilling, D., Walker, D., Exton, J., Binnie, J. \& Sabaou, N (2001) Sequence stratigraphy and sedimentology of the late Triassic TAG-I (Blocks 401/402, Berkine Basin, Algeria). Mar. Petrol. Geol., 18, 959-981.

Turner, P. \& SHERIF, H. (2007) A giant Late Triassic-Early Jurassic evaporitic basin on the Saharan Platform, North Africa. In: Evaporites through space and time (Ed. by B.C. Schreiber, S. Lugli \& M. Babel), Geol. Soc. Lond., Spec. Publ., 285, 87-105.

Underdown, R. (2006) An integrated basin modelling study of the Ghadames Basin, North Algeria. PhD thesis, University of Manchester, United Kingdom.

Underdown, R., Redfern, J. \& Lisker, F. (2007) Constraining the burial history of the Ghadames basin, North Africa: an integrated analysis using sonic velocities, vitrinite reflectance and apatite fission track ages. Basin Res., 19, 557-578. 
733 Wilson, M. \& GuiRAud, R. (1992) Magmatism and rifting in Western and Central Africa, from 734 Late Jurassic to Recent times. Tectonophysics, 213, 203-225.

735 Wilson, M., Guiraud, R., Moreau, C. \& Bellion, Y.J.C. (1998) Late Permian to Recent 736 magmatic activity on the African-Arabian margin of Tethys. In: Petroleum geology of North 737 Africa (Ed. by D.S. MacGregor, R.T.J. Moody \& D.D. Clark-Lowes), Geol. Soc. Lond., Spec. 738 Publ., 132, 231-263.

739 Wygrala, B.P. (1989) Integrated study of an oil field in the southern Po basin, northern Italy. $740 \mathrm{PhD}$ thesis, Köln University, Research Centre Jülich, Germany.

741 Yahi, N., Schaefer, R.G. \& LitTKe, R. (2001) Petroleum generation and accumulation in the 742 Berkine Basin, eastern Algeria. AAPG Bull., 85, 1439-1467.

743 Yarmolyuk, V.A. \& KuZNETSOV, Y.Y. (1977) Geological map of Africa. Ministry of Geology 744 of the USSR, Moscow, Russia, scale 1:5,000,000, 9 sheets.

745 Zanguina, M., Bruneton, A. \& Gonnard, R. (1998) An introduction to the petroleum 746 potential of Niger. J. Petrol. Geol., 21, 83-103. 
748

749

750

751

752

753

754

755

756

757

758

759

760

761

762

763

764

765

766

767

768

769

770

771

772

773

774

775

\section{List of Tables}

Table 1: Vitrinite reflectance data from Well A, Illizi basin, Algeria.

Table 2: Rock-Eval pyrolysis data from Well A, Illizi basin, Algeria.

Table 3: Apatite fission-track data from Well A, Illizi basin, Algeria.

\section{List of Figures}

Figure 1: (A) Topographic map of North Africa showing the Hoggar and Aïr massifs, and location of other Cenozoic volcanic areas including Tibesti and Darfur (Lesquer et al., 1988). (B) Simplified geology map of the Hoggar and Aïr massifs and flanking sedimentary basins (adapted from Yarmolyuk \& Kuznetsov, 1977; Choubert \& Faure-Muret, 1990; LeFranc \& Guiraud, 1990; Genik, 1993). Dated Mesozoic sediments that unconformably overlie basement (Serouenout and Amguid localities) are highlighted. Preserved Cenozoic sediments described in the text are located in the Tademait region. Location of Tin Fouyé Tabankort field (TFT) is noted where post-Hercynian deposits are preserved. Other information includes locations of thermal maturity data (Well A, Akouta and Arlit), new apatite fission track data (Well A), and published apatite thermochronology sample sites (Hoggar, Aïr, Ahnet, Tihemboka, Qarqaf Arch). Note that Logan and Duddy (1998) study includes both apatite fission track, and zircon fission track analysis. Refer to Figure 7 for illustration of the north-south transect (A-A') across the Hoggar Massif into the flanking basins.

Figure 2: (A) Actual Well A thermal maturity data (black circles) versus modelled thermal maturity profile (black line) according to depth. Models 1 and 2 maturity profiles are identical. The default profile illustrates predicted maturity if no additional burial is assumed. Present-day thermal maturity is higher than what would be expected from current burial depths (default maturity profile shown by dashed red line) indicating that these rocks have been hotter in the past. (B) Actual Well A fission-track ages (red circles) versus modelled fission-track ages (blue squares, Model 1; red squares, Model 2) according to depth. Most modelled fission-track ages for the actual grain populations for Models 1 and 2 overlie except for GC1085-2 (Visean). All samples provide fission-track ages that are younger than their corresponding depositional ages, 
and show a trend of decreasing fission-track age with depth due to greater degree of annealing. The default profile illustrates the predicted fission-track ages for apatites with $0.1 \mathrm{wt} . \%$ chlorine content if no additional burial is assumed. The measured fission-track ages are routinely younger than the default profile, consistent with the interpretation that this stratigraphic sequence has experienced hotter temperatures in the past. The predicted profile from the preferred Well A model (Model 1), also assuming a chlorine content of $0.1 \mathrm{wt} . \%$, provides a much better fit to the data. Samples with higher chlorine contents will be more resistant to annealing for a given thermal history. Fission-track modelling was carried out with HeFTy using the annealing kinetics of Ketcham et al. (2007).

Figure 3: Inverse modelling of the (A) Namurian sample GC1085-1 and the (B) deeper Devonian-Silurian sample combined from GC1085-6, GC1085-7 and GC1085-8. The models were run until 10,000 good paths were identified. The vertices of the good paths (GOF $>0.5)$ are highlighted in purple, while the vertices of the acceptable paths $(\mathrm{GOF}>0.05)$ are highlighted in green. The best-fit of all the inverse model solutions is highlighted by the black line in the thermal history plot. These solutions are non-unique and simply represent the best-fit of 10,000 different thermal histories that can provide a good fit to the measured data.

Figure 4: 1D thermal history models for Well A calibrated to thermal maturity and fission-track data. (A) Model 1 assumes maximum burial during the Eocene. (B) Model 2 assumes maximum burial during the Middle Cretaceous at the Austrian tectonic event. Additionally, slightly more Carboniferous deposition in Model 2 (50m) with $25 \mathrm{~m}$ less Hercynian erosion was required to best match maturity. While these solutions are non-unique, the new data require significant additional burial to match the peak paleotemperature constraints, followed by the onset of significant exhumation during the Eocene. Thermal history modelling was carried out using Genesis.

Figure 5: Temperature-time (T-t) histories from Model 1 for (A) the Namurian sample (GC1085-1) and (B) the combined Devonian-Silurian samples (GC1085-6, GC1085-7 and GC1085-8) exported from Genesis into HeFTy. Forward modelling of the T-t pathways in HeFTy provide a very good fit $(\mathrm{GOF}>0.85)$ for the track length distribution in both samples and for the fission-track age in the Devonian-Silurian samples. The goodness-of-fit is lower for the 
805 fission-track age in the Namurian sample and this may be due to preservation of pre-depositional 806 inheritance as this sample was not fully annealed during burial.

807 Figure 6: Temperature-time (T-t) histories from Model 2 for (A) theNamurian sample (GC1085808 1) and (B) the combined Devonian-Silurian samples (GC1085-6, GC1085-7 and GC1085-8) 809 exported from Genesis into HeFTy. Forward modelling of the T-t pathways in HeFTy provide a 810 very good fit $(\mathrm{GOF}>0.85)$ for the track length distribution in both samples and for the fission811 track age in the Devonian-Silurian samples. The goodness-of-fit is lower for the fission-track age 812 in the Namurian sample and this may be due to preservation of pre-depositional inheritance as 813 this sample was not fully annealed during burial.

814 Figure 7: Schematic structural section across the Hoggar Massif from the Berkine Basin in the 815 north to the Iullemmeden Basin in the south (see transect in Fig. 1). Note that the Hoggar had an 816 earlier history of uplift with significant erosion of the Paleozoic sequence during the Hercynian 817 orogeny. Preserved thicknesses are taken from well data (Illizi-Berkine), geology maps and 818 published cross sections (Iullemmeden Basin, Zanguina et al., 1998; Genik, 1993; Dautria \& 819 Lesquer, 1989). The eroded stratigraphy of the Tim Mersoï, Hoggar and Illizi regions is 820 projected above the present day surface and calibrated to $\sim 1 \mathrm{~km}$ of exhumation in Well A, $\sim 0.9$ $8211.6 \mathrm{~km}$ exhumation in the Serouenout area, and peak burial depths of $\sim 1.7-2.3 \mathrm{~km}$ for the Visean 822 projected from the Arlit area. Note that the actual magnitude of exhumation in Arlit/Arouta (on 823 the flank of Aïr; Fig. 1) is higher than where it is projected on this section (Carboniferous at 824 surface). Regional data suggests portions of the Central Hoggar may have been inundated with > $8251 \mathrm{~km}$ of Upper Cretaceous - lower Paleogene sediment. Cenozoic rock uplift across the Hoggar 826 occurred over a distance of $>1,500 \mathrm{~km}$ from north to south, as indicated by the tilted Cenozoic 827 stratigraphy in the Berkine and Iullemmeden basins. The magnitude of rock uplift, as opposed to 828 exhumation, reaches in excess of $2 \mathrm{~km}$ within the core of the Hoggar Massif. Deposition of 829 Upper Eocene-Pliocene sediments (the "Continental Terminal”) across Saharan Africa (Kilian, 830 1931) may represent the onset of clastic sedimentation derived from the growing intracratonic 831 swells. 


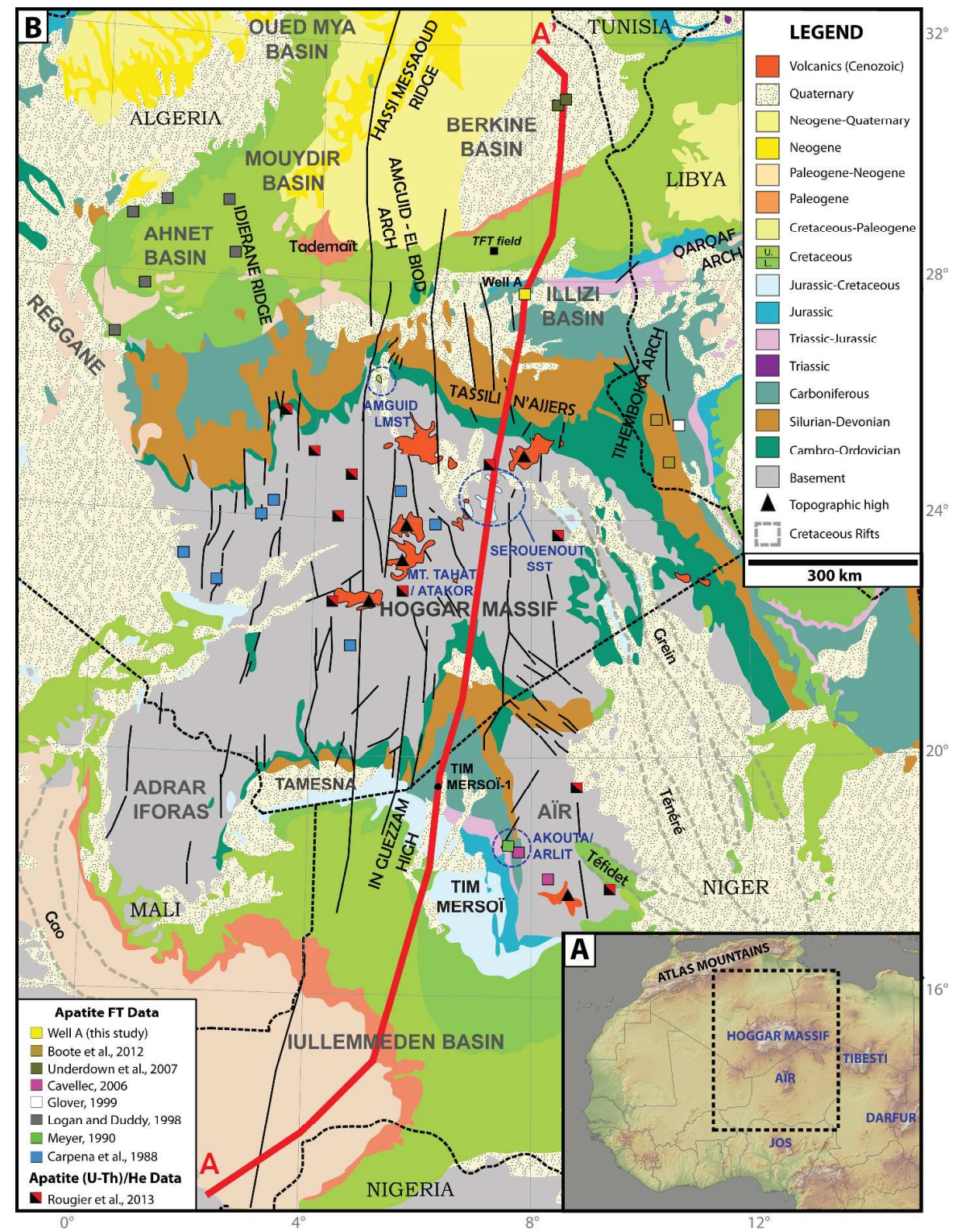

Figure 1: (A) Topographic map of North Africa showing the Hoggar and Airr massifs, and location of other Cenozoic volcanic areas including Tibesti and Darfur (Lesquer et al., 1988). (B) Simplified geology map of the Hoggar and Aïr massifs and flanking sedimentary basins (adapted from Yarmolyuk \& Kuznetsov, 1977; Choubert \& Faure-Muret, 1990; LeFranc \& Guiraud, 1990; Genik, 1993). Dated Mesozoic sediments that unconformably overlie basement (Serouenout and Amguid localities) are highlighted. Preserved Cenozoic sediments described in the text are located in the Tademaït region. Location of Tin Fouyé Tabankort field (TFT) is noted where post-Hercynian deposits are preserved. Other information includes locations of thermal maturity data (Well A, Akouta and Arlit), new apatite fission track data (Well A), and published apatite thermochronology sample sites (Hoggar, Aïr, Ahnet, Tihemboka, Qarqaf Arch). Note that Logan and Duddy (1998) study includes both apatite fission track, and zircon fission track analysis. Refer to Figure 7 for illustration of the north-south transect $\left(A-A^{\prime}\right)$ across the Hoggar Massif into the flanking basins. 
Figure 2

(A) Maturity (Well A)

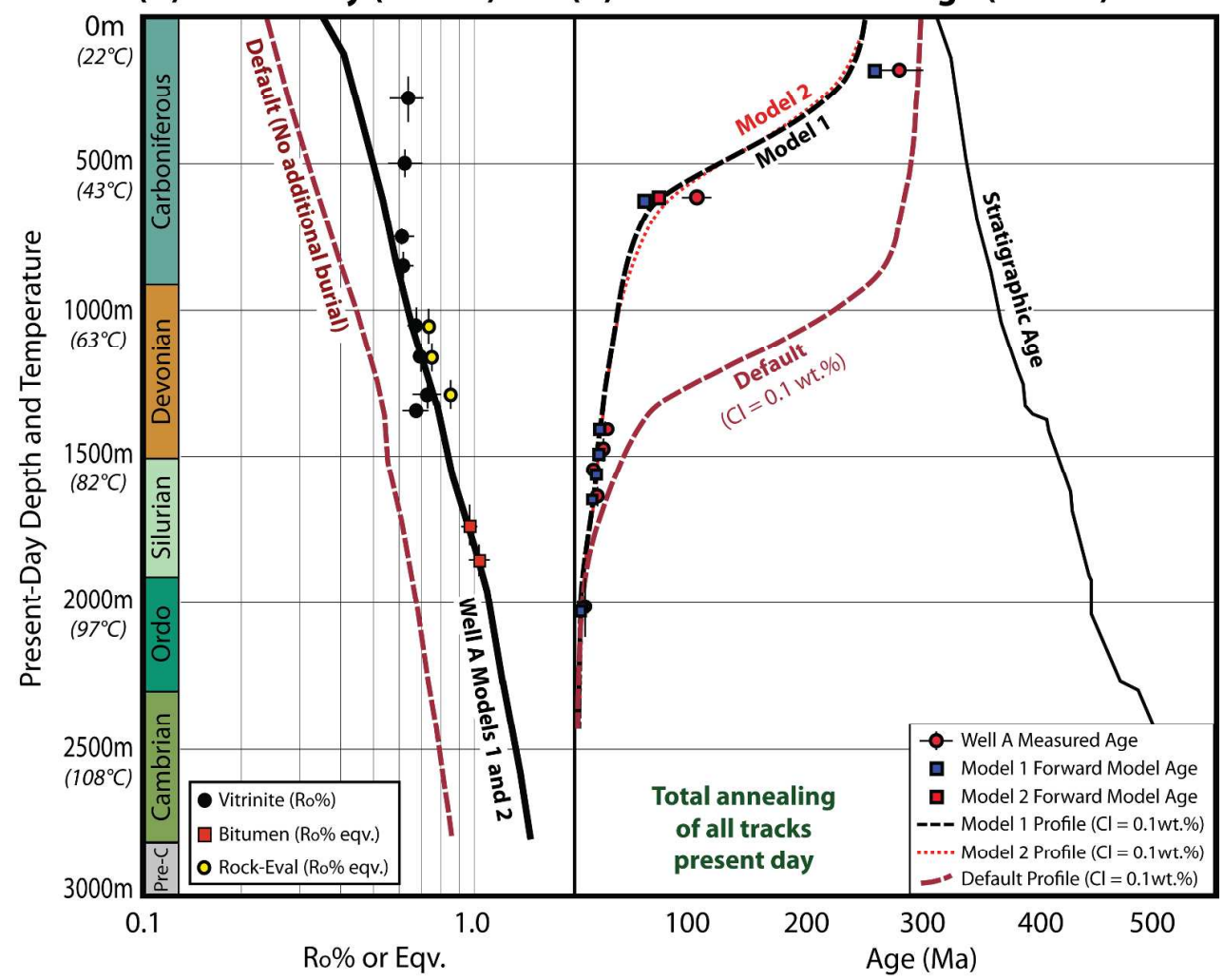

Figure 2: (A) Actual Well A thermal maturity data (black circles) versus modelled thermal maturity profile (black line) according to depth. Models 1 and 2 maturity profiles are identical. The default profile illustrates predicted maturity if no additional burial is assumed. Present-day thermal maturity is higher than what would be expected from current burial depths (default maturity profile shown by dashed red line) indicating that these rocks have been hotter in the past. (B) Actual Well A fission-track ages (red circles) versus modelled fission-track ages (blue squares, Model 1; red squares, Model 2) according to depth. Most modelled fission-track ages for the actual grain populations for Models 1 and 2 overlie except for GC1085-2 (Visean). All samples provide fission-track ages that are younger than their corresponding depositional ages, and show a trend of decreasing fission-track age with depth due to greater degree of annealing. The default profile illustrates the predicted fission-track ages for apatites with $0.1 \mathrm{wt}$. $\%$ chlorine content if no additional burial is assumed. The measured fission-track ages are routinely younger than the default profile, consistent with the interpretation that this stratigraphic sequence has experienced hotter temperatures in the past. The predicted profile from the preferred Well A model (Model 1), also assuming a chlorine content of 0.1 wt. \%, provides a much better fit to the data. Samples with higher chlorine contents will be more resistant to annealing for a given thermal history. Fission-track modelling was carried out with HeFTy using the annealing kinetics of Ketcham et al. (2007). 

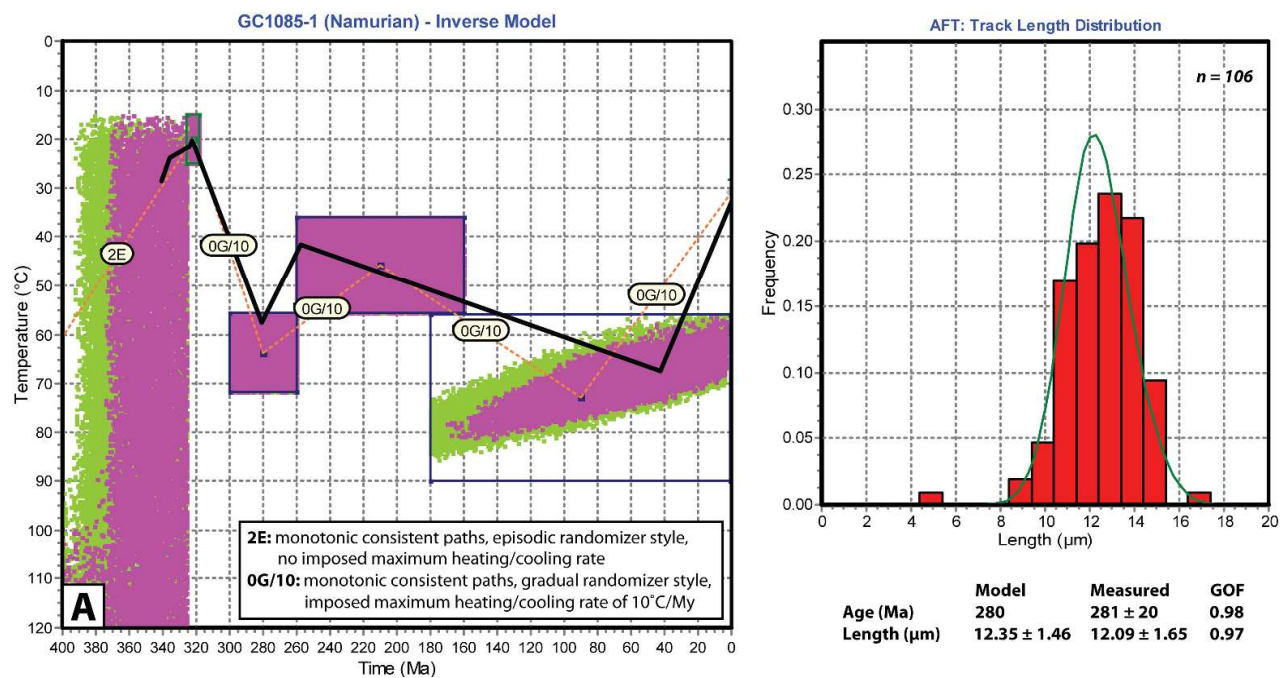
$\begin{array}{llll} & \text { Model } & \text { Measured } & \text { GOF } \\ \text { Age (Ma) } & 280 & 281 \pm 20 & 0.98 \\ \text { Length }(\mu \mathrm{m}) & 12.35 \pm 1.46 & 12.09 \pm 1.65 & 0.97\end{array}$
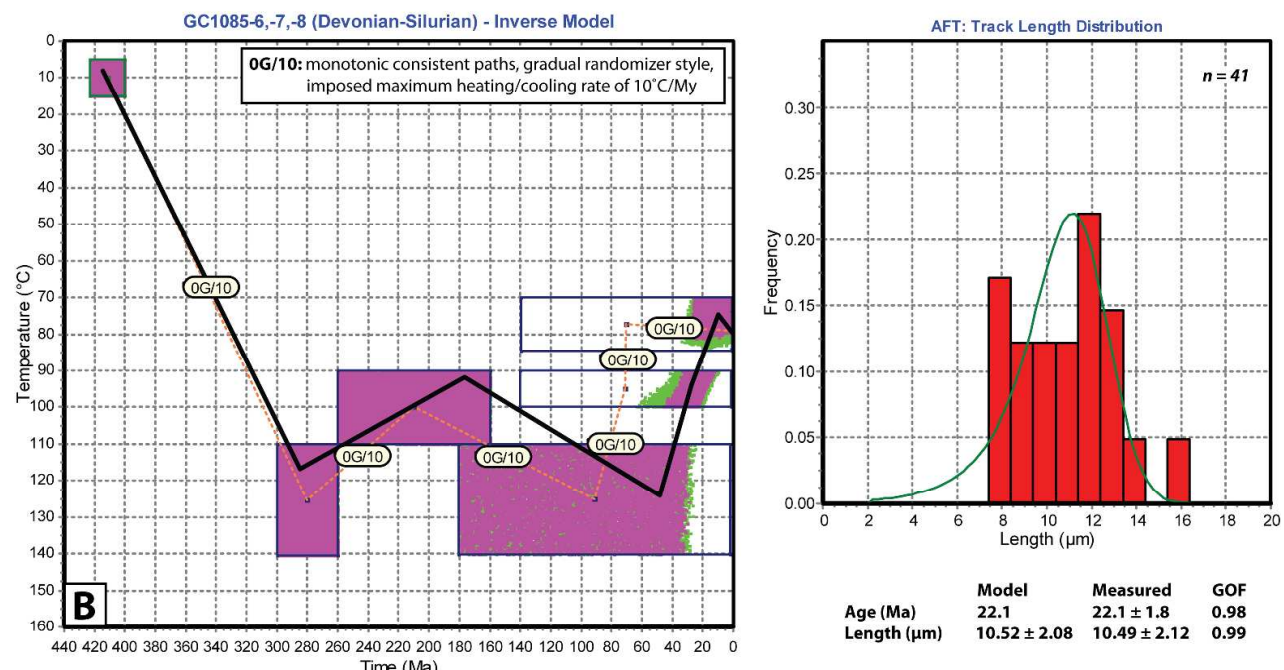

Figure 3

Figure 3: Inverse modelling of the (A) Namurian sample GC1085-1 and the (B) deeper Devonian-Silurian sample combined from GC1085-6, GC1085-7 and GC1085-8. The models were run until 10,000 good paths were identified. The vertices of the good paths (GOF > 0.5) are highlighted in purple, while the vertices of the acceptable paths (GOF > 0.05) are highlighted in green. The best-fit of all the inverse model solutions is

highlighted by the black line in the thermal history plot. These solutions are non-unique and simply represent the best-fit of 10,000 different thermal histories that can provide a good fit to the measured data. 
Figure 4
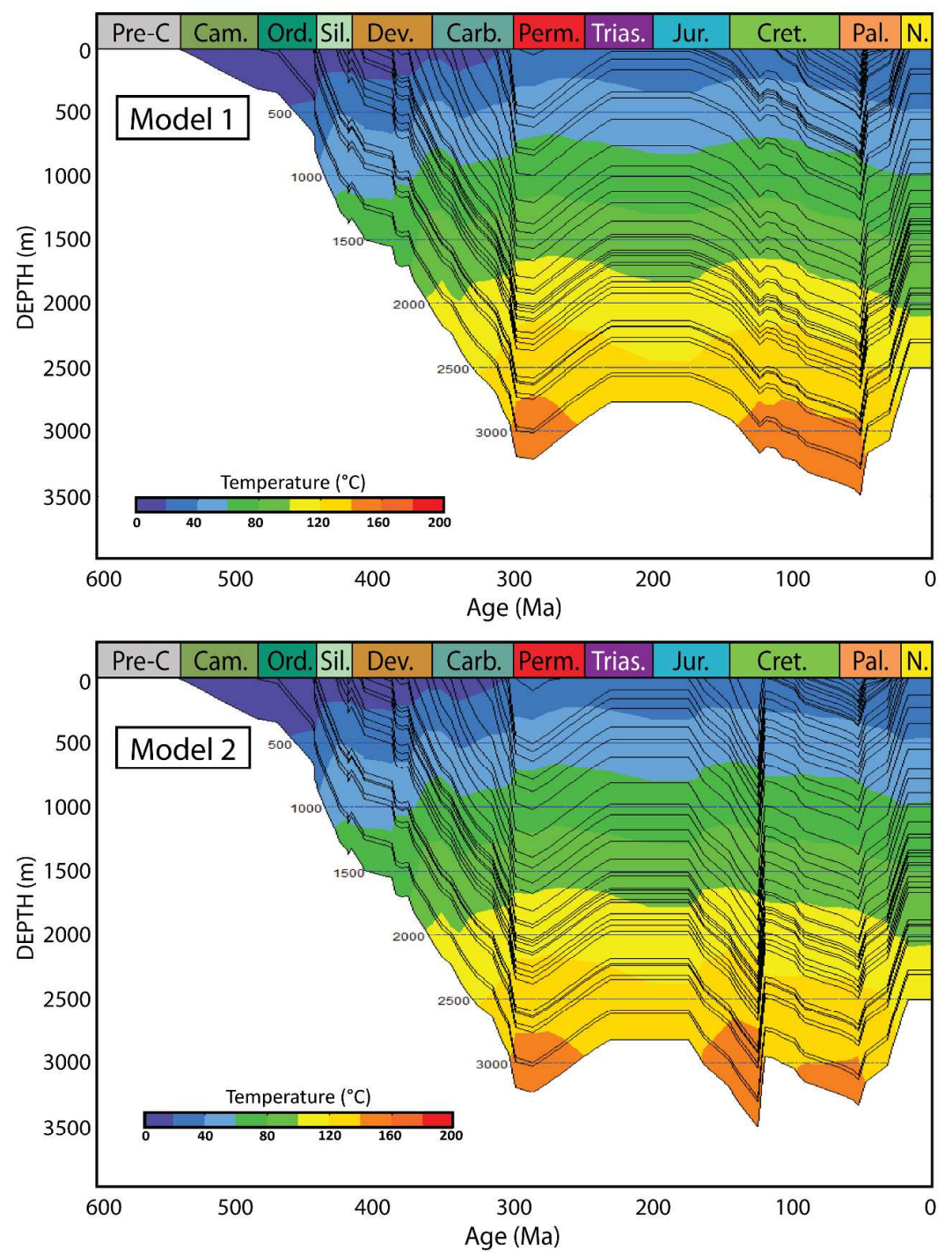

Figure 4: 1D thermal history models for Well A calibrated to thermal maturity and fission-track data. (A) Model 1 assumes maximum burial during the Eocene. (B) Model 2 assumes maximum burial during the Middle Cretaceous at the Austrian tectonic event. Additionally, slightly more Carboniferous deposition in Model $2(50 \mathrm{~m})$ with $25 \mathrm{~m}$ less Hercynian erosion was required to best match maturity. While these solutions are non-unique, the new data require significant additional burial to match the peak paleotemperature constraints, followed by the onset of significant exhumation during the Eocene. Thermal history modelling was carried out using Genesis. 

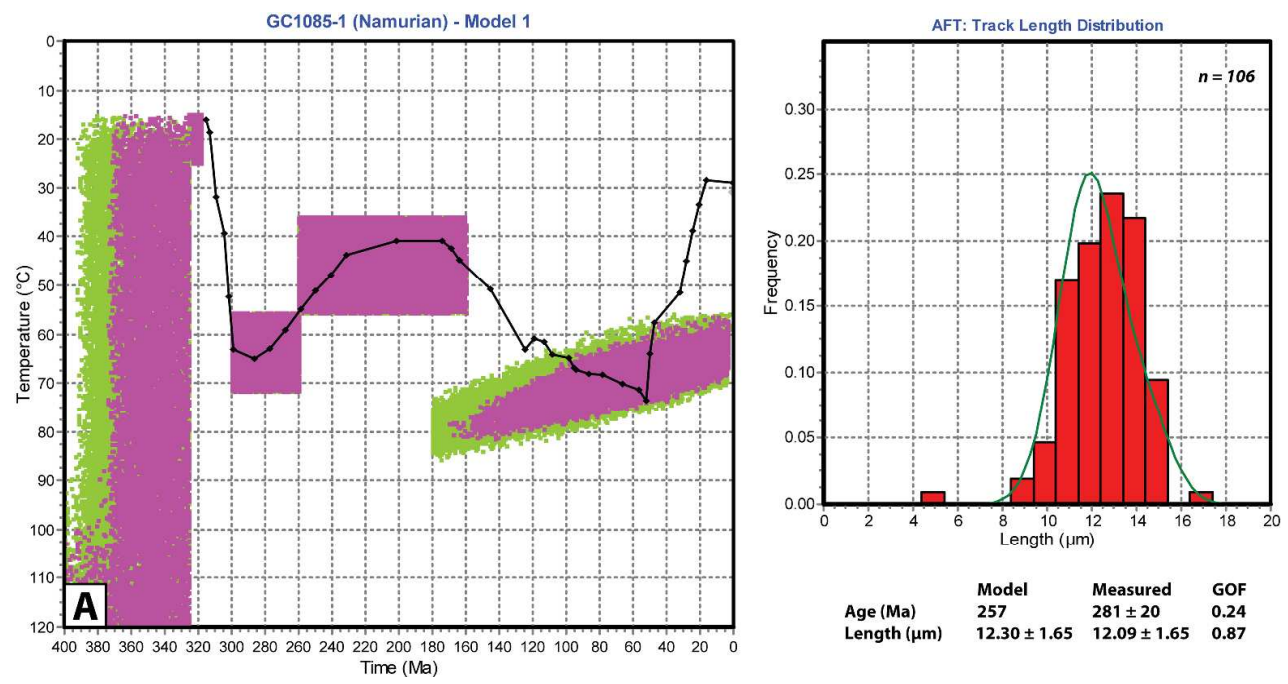
$\begin{array}{llll} & \text { Model } & \text { Measured } & \text { GOF } \\ \text { Age }(\mathrm{Ma}) & 257 & 281 \pm 20 & 0.24 \\ \text { Length }(\mu \mathrm{m}) & 12.30 \pm 1.65 & 12.09 \pm 1.65 & 0.87\end{array}$
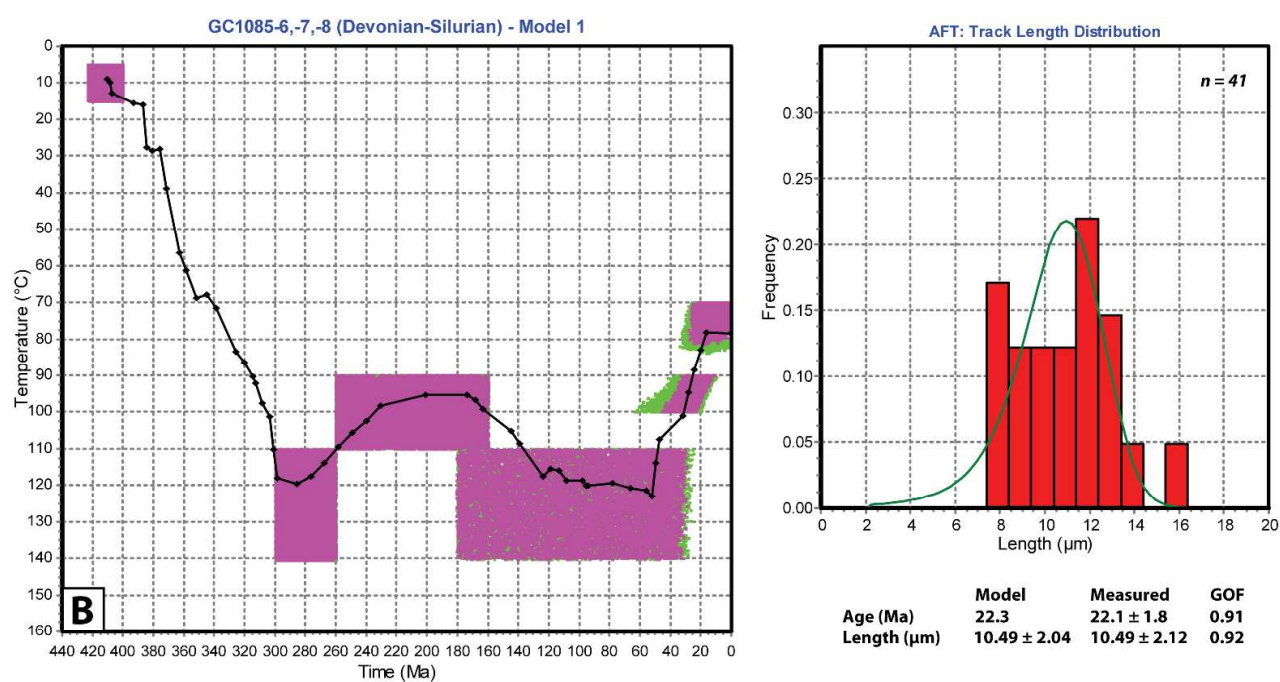

Figure 5

Figure 5: Temperature-time (T-t) histories from Model 1 for (A) the Namurian sample (GC1085-1) and (B) the combined Devonian-Silurian samples (GC1085-6, GC1085-7 and GC1085-8) exported from Genesis into HeFTy. Forward modelling of the T-t pathways in HeFTy provide a very good fit (GOF > 0.85) for the track length distribution in both samples and for the fission-track age in the Devonian-Silurian samples. The goodness-of-fit is lower for the fission-track age in the Namurian sample and this may be due to preservation of pre-depositional inheritance as this sample was not fully annealed during burial. 

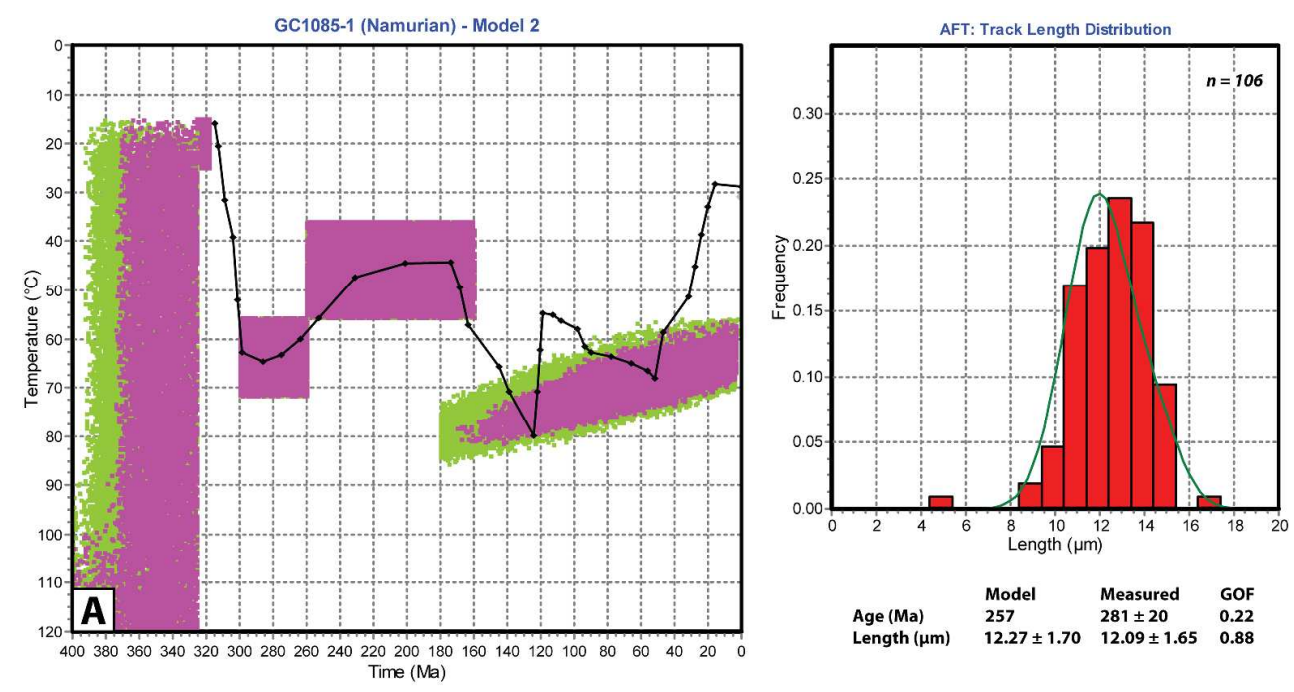
$\begin{array}{llll} & \text { Model } & \text { Measured } & \text { GOF } \\ \text { Age }(\text { Ma) } & 257 & 281 \pm 20 & 0.22 \\ \text { Length }(\mu \mathrm{m}) & 12.27 \pm 1.70 & 12.09 \pm 1.65 & 0.88\end{array}$
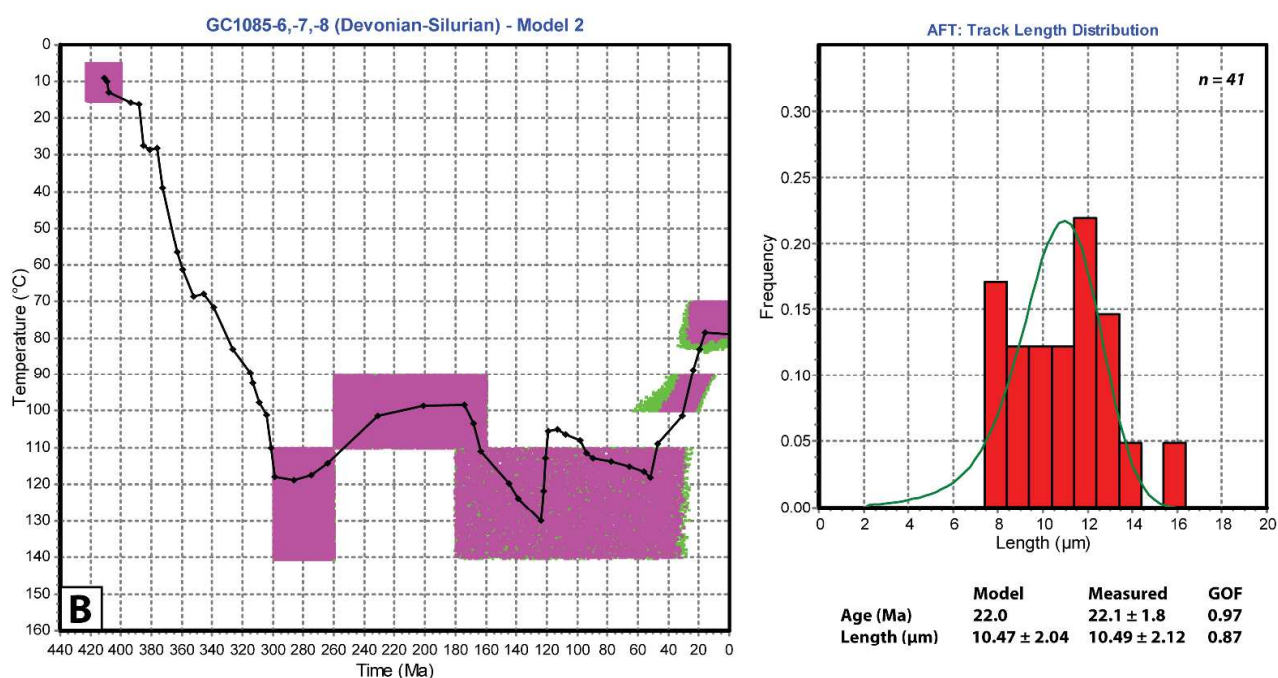

Figure 6

Figure 6: Temperature-time (T-t) histories from Model 2 for (A) theNamurian sample (GC1085-1) and (B) the combined Devonian-Silurian samples (GC1085-6, GC1085-7 and GC1085-8) exported from Genesis into HeFTy. Forward modelling of the T-t pathways in HeFTy provide a very good fit (GOF > 0.85) for the track length distribution in both samples and for the fission-track age in the Devonian-Silurian samples. The goodness-of-fit is lower for the fission-track age in the Namurian sample and this may be due to preservation of pre-depositional inheritance as this sample was not fully annealed during burial. 
Figure 7

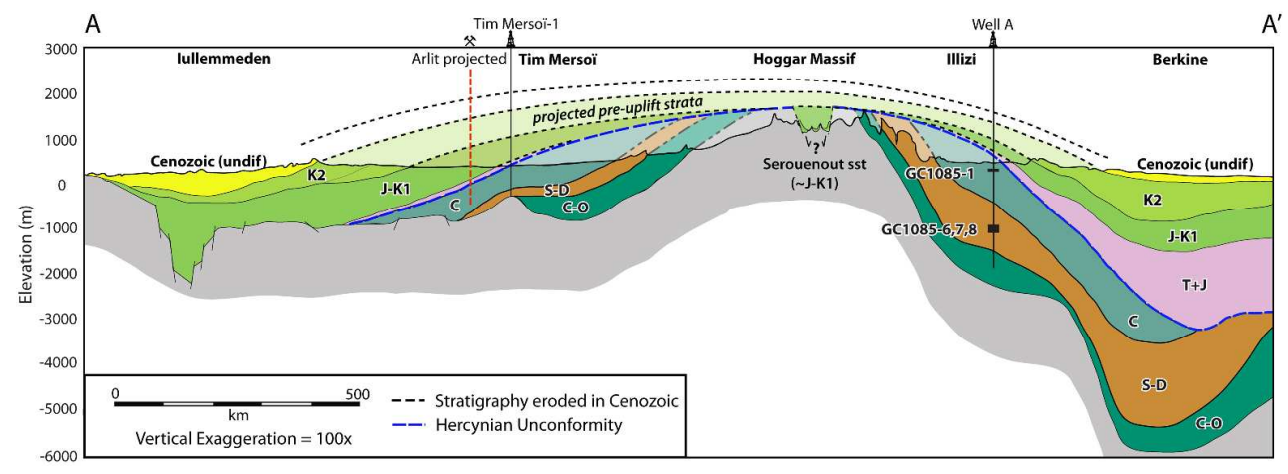

Figure 7: Schematic structural section across the Hoggar Massif from the Berkine Basin in the north to the Iullemmeden Basin in the south (see transect in Fig. 1). Note that the Hoggar had an earlier history of uplift with significant erosion of the Paleozoic sequence during the Hercynian orogeny. Preserved thicknesses are

taken from well data (Illizi-Berkine), geology maps and published cross sections (Iullemmeden Basin, Zanguina et al., 1998; Genik, 1993; Dautria \& Lesquer, 1989). The eroded stratigraphy of the Tim Mersoï, Hoggar and Illizi regions is projected above the present day surface and calibrated to $\sim 1 \mathrm{~km}$ of exhumation in Well A, 0.9-1.6 km exhumation in the Serouenout area, and peak burial depths of $\sim 1.7-2.3 \mathrm{~km}$ for the Visean projected from the Arlit area. Note that the actual magnitude of exhumation in Arlit/Arouta (on the flank of Air; Fig. 1) is higher than where it is projected on this section (Carboniferous at surface). Regional data suggests portions of the Central Hoggar may have been inundated with $>1 \mathrm{~km}$ of Upper Cretaceous lower Paleogene sediment. Cenozoic rock uplift across the Hoggar occurred over a distance of $>1,500 \mathrm{~km}$ from north to south, as indicated by the tilted Cenozoic stratigraphy in the Berkine and Iullemmeden basins. The magnitude of rock uplift, as opposed to exhumation, reaches in excess of $2 \mathrm{~km}$ within the core of the Hoggar Massif. Deposition of Upper Eocene-Pliocene sediments (the "Continental Terminal") across Saharan Africa (Kilian, 1931) may represent the onset of clastic sedimentation derived from the growing intracratonic swells. 


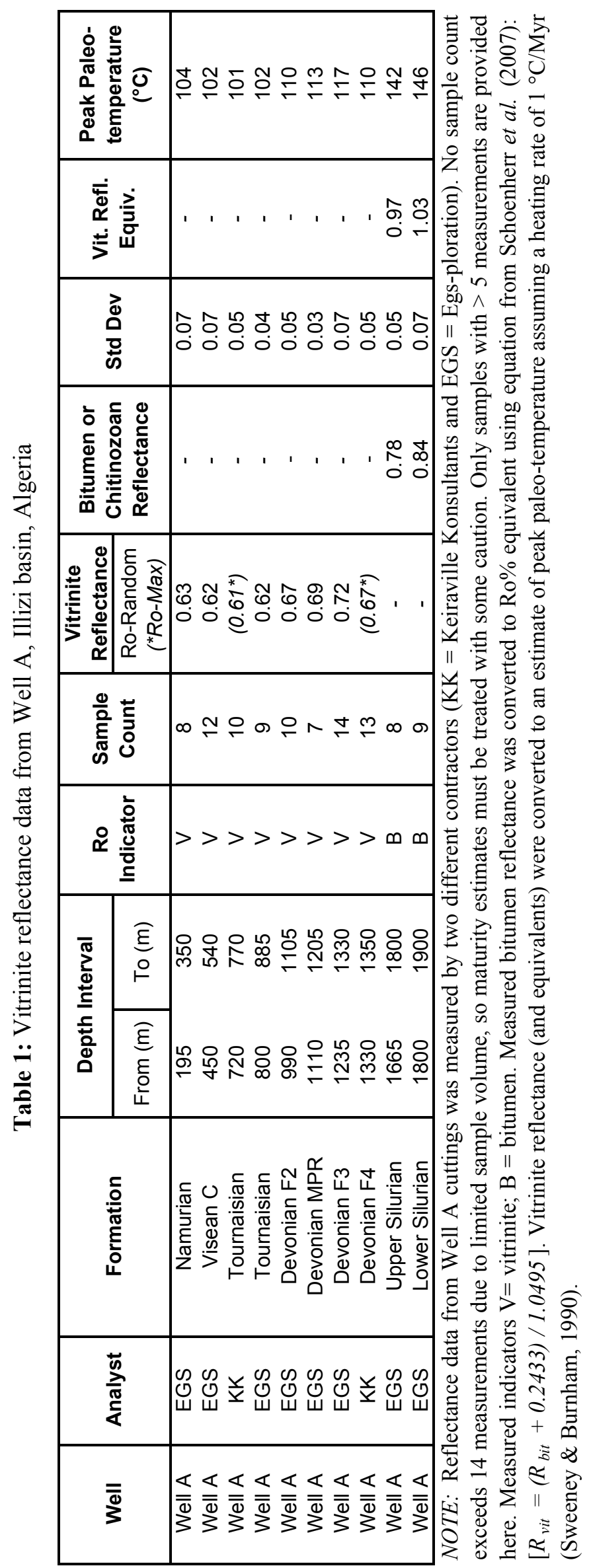

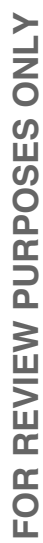




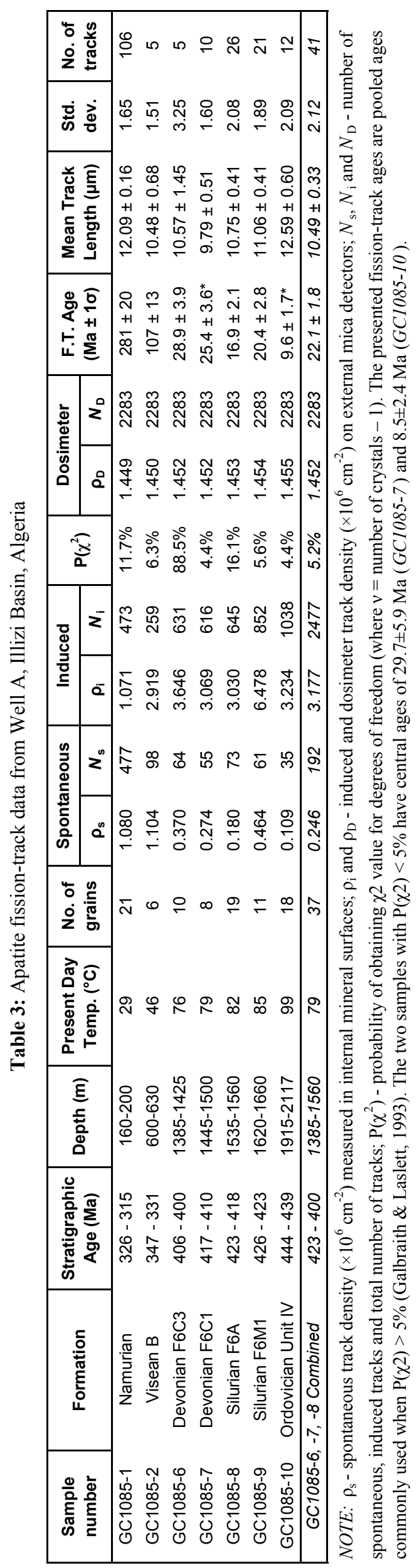

